\title{
Türkiye’nin ve Tarım Bölgelerinin Tarımsal Mekanizasyon Düzeyindeki Değişimlerin Son On Yıl (2010-2019) ve Gelecek Yıllar (2020-2030) İçin Değerlendirilmesi
}

\author{
Ali AYBEK ${ }^{1}$, Hamza KUZU2, Hayrettin KARADÖL ${ }^{3}$ \\ 1,2,3Kahramanmaraş Sütçü İmam Üniversitesi, Ziraat Fakültesi, Biyosistem Mühendisliği Bölümü, 46100, Kahramanmaraş/TÜRKIYE \\ ${ }^{1}$ https://orcid.org/0000-0003-3036-8204, ${ }^{2}$ https://orcid.org/0000-0001-8585-4467, ${ }^{3}$ https://orcid.org/0000-0002-5062-0887, \\ $\bowtie:$ aaybek@ksu.edu.tr
}

\section{ÖZET}

Bu çalışmada, Türkiye İstatistik Kurumu (TUIK) verilerine göre Türkiye'nin ve on tarım bölgesinin; son 10 yıla (2010-2019) ait tarımsal mekanizasyon düzeyi gösterge değerleri ( $\mathrm{kW}$ ha-1, traktör sayısı 1000 ha $^{-1}$, ha traktör ${ }^{-1}$, makina traktör ${ }^{-1}$ ) belirlenmiş ve gelecek yıllar (2020-2030) için $\mathrm{kW}$ ha ${ }^{-1}$ değeri trend analizi yardımıyla tahmin edilmiş ve değerlendirilmiştir. Türkiye'nin on tarım bölgesi ve Türkiye genelinde yıllara göre mekanizasyon düzeyi göstergelerinden $\mathrm{kW} \mathrm{ha}^{-1}$ ve traktör 1000 ha $^{-1}$ değerleri artmış, makina traktör ${ }^{-1}$ değeri ise azalmıştır. $\mathrm{kW}$ ha $^{-1}$ değeri; en yüksek Ege Bölgesinde (2.86-3.72 kW ha-1), en düşük Doğu Karadeniz Bölgesinde (0.35-0.44 kW ha-1) oluşmuş, Türkiye genelinde son on yılda ortalama \%3.22 artış göstermiş ve $1.67-2.22 \mathrm{~kW}$ ha ${ }^{-1}$ olarak gerçekleşmiştir. Gelecek yıllar (2020-2030) için $\mathrm{kW}$ ha-1 değeri; Türkiye ve tüm tarım bölgelinde yıllara göre artış göstereceği tahmin edilmiştir. Gelecek yıllar (20202030) için ortalama artış değerleri \%0.89-3.18 arasında gerçekleşeceği öngörülmektedir. $\mathrm{kW}$ ha $^{-1}$ değeri; Türkiye geneli için 2020 yılında 2.27, 2025 yılında 2.55 ve 2030 yılında 2.84 olması tahmin edilmektedir. Makina traktör ${ }^{-1}$ oranındaki azalma; on yıllık süreçte makina sayılarındaki artış oranlarının traktör sayılarındaki artış oranlarından daha az olmasından kaynaklanmaktadır.

\section{Araştırma Makalesi}

Makale Tarihçesi

Geliş Tarihi : 02.06.2020

Kabul Tarihi : 15.09 .2020

\section{Anahtar Kelimeler}

Mekanizasyon düzeyi

Türkiye

Tarım bölgeleri

Trend analizi

Evaluation for the Last Ten Years (2010-2019) and Next Years (2020-2030) of Changes in Agricultural Mechanization Level of Turkey and the Agricultural Regions

\section{ABSTRACT}

In this study, agricultural mechanization level indicator values $(\mathrm{kW}$ ha $^{-1}$, number of tractors 1000 ha $^{-1}$, ha tractor ${ }^{-1}$, machine tractor-1) for the last ten years (2010-2019) of Turkey and ten agricultural regions was determined based on the Turkey Statistical Institute (TSI) data, and $\mathrm{kW} \mathrm{ha}^{-1}$ value for the next ten years $(2020-2030)$ was estimated and evaluated with the help of trend analysis. $\mathrm{kW} \mathrm{ha}{ }^{-1}$, and tractor $1000 \mathrm{ha}^{-1}$ values from the mechanization level indicators increased, and machine tractor $^{-1}$ value decreased in Turkey's ten agricultural regions and in Turkey overall by years. The highest $\mathrm{kW}$ ha-1 value was found in the Aegean region (2.86-3.72 $\left.\mathrm{kW} \mathrm{ha}^{-1}\right)$, while the lowest was seen in the Eastern Black Sea region $\left(0.35-0.44 \mathrm{~kW}^{-1} \mathrm{a}^{-1}\right)$. Overall, $\mathrm{kW}$ $\mathrm{ha}^{-1}$ value have increased with an average of $3.22 \%$, and occurred as $1.67-2.22 \mathrm{~kW} \mathrm{ha}^{-1}$ in the last decade in Turkey. $\mathrm{kW} \mathrm{ha}{ }^{-1}$ value for the next ten years (2020-2030) in Turkey and all agricultural regions is estimated to increase by years. Average increase values for the upcoming ten years (2020-2030) are expected to be between 0.89$3.18 \%$. $\mathrm{kW} \mathrm{ha}^{-1}$ value anticipated as 2.27 in $2020,2.55$ in 2025 and as 2.84 in 2030 in Turkey. The decrease in the ratio of machine tractor ${ }^{-1}$ is due to the fact that the increase rates in the number of machines in the ten-years period is less than the increase rates of the tractor numbers.

\section{Research Article}

$\begin{array}{ll}\text { Article History } & \\ \text { Received } & : 02.06 .2020 \\ \text { Accepted } & : 15.09 .2020\end{array}$

Keywords

Mechanization level

Turkey

Agricultural regions

Trend analysis 


\begin{tabular}{ll}
\hline Atıf İçin: & $\begin{array}{l}\text { Aybek A, Kuzu H, Karadöl H 2020. Türkiye’nin ve Tarım Bölgelerinin Tarımsal Mekanizasyon Düzeyindeki } \\
\text { Değişimlerin Son On Yıl (2010-2019) ve Gelecek Ylllar (2020-2030) İçin Değerlendirilmesi. KSÜ Tarım ve Doğa }\end{array}$ \\
& $\begin{array}{l}\text { Derg 24 (2): 319-336. https://doi.org/10.18016/ksutarimdoga.vi.747163 } \\
\text { To Cite: }\end{array}$ \\
& $\begin{array}{l}\text { Aybek A, Kuzu H, Karadöl H 2020. Evaluation for the Last Ten Years (2010-2019) and Next Years (2020-2030) } \\
\text { of Changes in Agricultural Mechanization Level of Turkey and the Agricultural Regions. KSU J. Agric Nat } \\
24(2): 319-336 . \text { https://doi.org/10.18016/ksutarimdoga.vi.747163 }\end{array}$ \\
\hline
\end{tabular}

\section{GİRİS}

Tarım sektörü; ekonomik, sosyal ve çevresel boyutlarıyla, dünyadaki tüm toplum kesimlerini yakından ilgilendirmektedir. Tarımsal üretim; bitkisel ve hayvansal ürünlerin üretilmesi, kalite ve veriminin yükseltilmesi, uygun koşullarda korunması, işlenip değerlendirilmesi ile pazarlanması alanında faaliyet göstermektedir (Doğan ve ark., 2015). Günümüzde kalitatif ve kantitatif olarak artan tarım ürünleri talebi ancak daha yoğun makinalaşma (mekanizasyon) ile karşılanabilecektir (Ulusoy ve ark., 2020). Gelişmiş ülkelerin tarımdaki verimliliği sağlamada önemli bir payı olan tarımda makina kullanımı veya mekanizasyon, ileri teknolojilerin uygulanmasını, ayrıca toprak, su, gübre, ilaç vd. girdilerin etkin kullanımını olanaklı kılarak tarımda verimliliği sağlayan önemli bir üretim aracıdır (Evcim ve ark., 2010). Tarımsal üretimde mekanizasyon, toprak hazırlığından ürün hasadına kadarki dönem içinde, toplam tarımsal üretim girdilerinin yaklaşık \%40-50'sini oluşturmaktadır (Ruiyin ve ark., 1999; Landers, 2000). Bu durum tarım işletmelerinde mekanizasyonun önemini artırmaktadır.

Bir ülkenin tarımsal mekanizasyon durumunun iki önemli göstergesi "Traktör Parkı" ile "Tarım Makinaları Parkı" ve bunların yıllar itibariyle değişimidir. Bu değişim, doğru istatistik yöntemlerle ve amaca uygun siniflandırmalarla izlenebilirse "Tarımsal Mekanizasyon Gelişme Yönleri" ne, dolayısıyla "Tarım Sektörünün Geleceği” ne de ışık tutabilecektir (Ulusoy ve ark. 2020). Tarımsal Mekanizasyon durumunu "Traktör+Makina" bütünlüğünde değerlendirmek için özellikle uluslararası karşılaştırmalarda yaygın olarak kullanılan bazı göstergeler vardır. Bunlar; traktör sayısı 1000 ha $^{-1}$, ha traktör ${ }^{-1}$, $\mathrm{kW}$ ha ${ }^{-1}$, makina sayısı traktör-1 'dür (Sabancı ve ark., 2003; Koçtürk ve Onurbaş Avcıŏlu, 2007; Evcim ve ark., 2010; Korucu ve ark., 2015; Altuntaş, 2016; Ulusoy ve ark., 2020). Bütün bu göstergeler, yerine göre kabul gören ölçütler olsa da temel bir eksiklik vardır. Ülkeleri traktör ve tarım makinaları bakımından karşılaştırmak, "Tarımsal İşletme Yapısı" ve "Tarımsal Üretim Paterni” farklıysa anlamsız kalır. Bir ülkenin genel ortalama değerleri, daha dar alanda "Bölge Bazlı", "İşletme Bazlı", "Ürün Bazlı" yorumlanırsa, hem değişim ve gelişmeyi daha doğru yansıtır hem de geleceğe yol gösterir (Ulusoy ve ark. 2020).

Son on yılda Türkiye ve bölgelerine ilişkin tarımsal mekanizasyon düzeyi ile ilgili bazı çalışmalar (Özgüven ve ark. 2010; Gökdoğan, 2012; Baran ve ark.,
2014; Korucu ve ark., 2015; Altuntaş, 2016; Sağlam ve Kuş, 2016; Abdikoğlu, 2019) yapılmıştır.

Tarım işletmelerinde, yapılan faaliyetlerin verimliliğinin izlenmesi için mekanizasyon düzeyinin her üretim sezonunda mutlaka bilimsel esaslara dayalı olarak değerlendirilmesi gerekmektedir. Bunun temel amacı gerek aynı bölge sinırlarında gerekse farklı ülkelerde benzer üretim koşullarında üretim yapan işletmelerin mekanizasyon uygulama yoğunlukları ve etkinlikleri açısından karşılaştırılmalarına ve değerlendirilmesine olanak sağlamasıdır. Tarımsal mekanizasyon düzeyi bölgelerin teknik ve ekonomik yapısına bağlı olarak değişim gösterebilmektedir (Koçtürk ve Onurbaş Avcıŏlu, 2007; Say ve ark., 2010; Korucu ve ark., 2015; Abdikoğlu, 2019). Tarımsal mekanizasyon düzeyinin, güncel verilerle ortaya konulması; ülkesel ve bölgesel düzeydeki tarımsal kalkınma planlarına katkı sağlayarak geleceğe yönelik doğru kararların alınmasında önemli rol oynayacaktır (Bayram ve Altuntaş, 2016).

Bu çalışmada, Türkiye'nin tarım bölgeleri bazında, son 10 yıla (2010-2019) ait tarımsal mekanizasyon düzeyi gösterge değerlerinin (traktör sayısı $1000 \mathrm{ha}^{-1}$, ha traktör ${ }^{-1}, \quad \mathrm{~kW} \quad \mathrm{ha}^{-1}$, makina sayısı traktör-1) hesaplanması yapılarak, yıllar içerisinde mekanizasyon düzeyinde meydana gelen değişimin belirlenmesi ve trend (eğilim) analizi ile gelecek yıllar (2020-2030) için işlenen alana düşen traktör gücünün $\left(\mathrm{kW} \mathrm{ha}^{-1}\right)$ tahmin edilmesi ve değerlendirilmesi amaçlanmıştır. Çalışmanın Türkiye ve tarım bölgelerinin mekanizasyon planlamalarına yön vermede katkı sağlayacağı ümit edilmektedir.

\section{MATERYAL ve METOD}

Çalışmanın verileri (tarım alanları, traktör sayıları, traktör güçleri ve tarım alet/makina sayıları), Türkiye İstatistik Kurumu (TÜİK) kayıtlarından alınmıştır (TÜİK, 2020). Veriler 2010-2019 yıllarını kapsayıp, on tarım bölgesine göre (Ekinci ve ark., 2010) oluşturulmuştur (Çizelge 1).

Tarım alanları belirlenirken ekili alanlar ve nadas alanlarının toplamları dikkate alınmıştır. Tarım alet ve makina sayıları belirlenirken Çizelge 2'de verilen ve traktörle çalıştırılan alet ve makinalar dikkate alınmıştır. Traktör sayıları belirlenirken sadece tekerlekli traktörler dikkate alınmış, paletli traktör sayıları hesaplamalara dahil edilmemiştir. Öncelikle traktörler tek akslı ve çift akslı olarak gruplandırılmış sonrasında her grup içerisinde de güç değerleri dikkate alınarak (Çizelge 3) sınıflandırmalar ve hesaplamalar 
yapılarak belirlenmiştir. Traktör güç değerleri beygir

dönüştürülmüştür.

gücü cinsinden olup, 0.736 ile çarpılarak kW'a

Çizelge 1. Türkiye'nin tarım bölgeleri ve kapsadığı iller

Table 1. Agricultural regions and provinces of Turkey

\begin{tabular}{l}
\hline Tarım bölgesi \\
\hline Akdeniz \\
Batı Anadolu \\
Batı Karadeniz \\
Doğu Karadeniz \\
Ege \\
Güney Doğu Anadolu \\
Kuzey Doğu Anadolu
\end{tabular}

Marmara

Orta Anadolu

Orta Doğu Anadolu
İller

Adana, Antalya, Burdur, Hatay, Isparta, Kahramanmaraş, Mersin, Osmaniye

Ankara, Karaman, Konya

Amasya, Bartın, Karabük, Kastamonu, Samsun, Sinop, Tokat, Zonguldak, Çankırı, Çorum

Artvin, Giresun, Gümüşhane, Ordu, Rize, Trabzon

Afyonkarahisar, Aydın, Denizli, Kütahya, Manisa, Muğla, Uşak, İzmir

Adıyaman, Batman, Diyarbakır, Gaziantep, Kilis, Mardin, Siirt, Şanlıurfa, Şırnak Ağrı, Ardahan, Bayburt, Erzincan, Erzurum, Iğdır, Kars

Balıkesir, Bilecik, Bolu, Bursa, Düzce, Edirne, Eskişehir, Kocaeli, Kırklareli, Sakarya, Tekirdağ, Yalova, Çanakkale, İstanbul

Aksaray, Kayseri, Kırıkkale, Kırşehir, Nevşehir, Niğde, Sivas, Yozgat

Bingöl, Bitlis, Elazığ, Hakkari, Malatya, Muş, Tunceli, Van

Cizelge 2. Hesaplamalarda kullanılan tarım alet/makina isimleri

Table 2. Agricultural tool/machine names used in calculations

\begin{tabular}{|c|c|c|}
\hline Kulaklı traktör pulluğu & Kombine hububat ekim makinesi & Yerfıstığı hasat makinesi \\
\hline Kulaklı anız pulluğu & Pnömatik ekim makinesi & Yerfıstığ harman makinesi \\
\hline Ark açma pulluğu & Fide dikim makinesi & $\begin{array}{l}\text { Traktörle çekilen çayır biçme } \\
\text { makinesi }\end{array}$ \\
\hline Dip kazan (subsoiler) & Patates dikim makinesi & Ot tırmığı \\
\hline Diskli anız pulluğu (vanvey) & Çapa makinesi & Balya makinesi \\
\hline Diskli tırmık (diskaro) & Kimyevi gübre dağıtma makinesi & Ot silaj makinesi \\
\hline Diskli traktör pulluğu & Ciftlik gübresi dağıtma makinesi & Misır silaj makinesi \\
\hline Dişli tırmık & $\begin{array}{l}\text { Kuyruk milinden hareketli } \\
\text { pülverizatör }\end{array}$ & $\begin{array}{l}\text { Sap döver ve harman makinesi } \\
\text { (batöz) }\end{array}$ \\
\hline Kombikürüm (karma tırmık) & Atomizör & $\begin{array}{l}\text { Sap toplamalı saman yapma } \\
\text { makinesi }\end{array}$ \\
\hline Kültivatör & Moto & Römork (tarım arabası) \\
\hline Merdane & Biçer bağlar makinesi & Meyve hasat makineleri \\
\hline Toprak frezesi (rotovatör) & Orak makinesi & Findık harman makinesi \\
\hline Sap parçalama makinesi & Misır hasat makinesi & Su tankeri (tarımda kullanılan) \\
\hline Set yapma makinesi & Pancar sökme makinesi & Taş toplama makinesi \\
\hline Anıza ekim makinesi & Kombine pancar hasat makinesi & Toprak burgusu \\
\hline $\begin{array}{l}\text { Traktörle çekilen hububat ekim } \\
\text { makinesi }\end{array}$ & Patates sökme makinesi & Toprak tesviye makinesi \\
\hline Üniversal ekim makinesi (mekanik) & Kombine patates hasat makinesi & Yem dağıtıcı römork \\
\hline
\end{tabular}

Çizelge 3. Traktörlerin güç hesaplamalarında kullanılan ortalama güç değerleri

Table 3. Average power values used in calculations of tractor power

\begin{tabular}{lc}
\hline Traktör grubu & Ortalama güç (BG) \\
\hline Tek akslı (1-5 BG) & 3.0 \\
Tek akslı (5 BG'den fazla) & 7.5 \\
Tek akslı (1-10 BG) & 5.5 \\
Tek akslı (11-24 BG) & 17.5 \\
Tek akslı (25-34 BG) & 29.5 \\
Tek akslı (35-50 BG) & 42.5 \\
Tek akslı (51-70 BG) & 60.5 \\
Tek akslı (70 BG'den fazla) & 85 \\
\hline
\end{tabular}

Tarım bölgeleri ve 2010-2019 yıllarına göre belirlenen; toplam tarım alanları Çizelge 4'de, toplam traktör sayıları Çizelge 5'de, ortalama traktör güç değerleri Çizelge 6'da, toplam traktör güç değerleri Çizelge 7'de ve toplam tarım alet/makina sayıları ise Çizelge 8'de verilmiştir. Son on yılda, hem tarım bölgelerinde hem de Türkiye genelinde; işlenen tarım alanlarında bir azalma (Çizelge 4), traktör sayılarında artış (Çizelge 5), ortalama traktör güç değerlerinde Doğu ve Batı Karadeniz Bölgeleri hariç bir artış (Çizelge 6), toplam traktör güç değerlerinde bir artış (Çizelge 7) tarım alet/makina sayılarında bir artış (Çizelge 8) olmuştur. 
Cizelge 4. Tarım bölgelerinin 2010-2019 yıllarındaki toplam tarım alanları (ha)

Table 4. Total agricultural areas (ha) of agricultural regions in 2010-2019

\begin{tabular}{|c|c|c|c|c|c|c|c|c|c|c|c|c|c|c|c|c|c|c|c|c|c|c|}
\hline \multirow[b]{2}{*}{ 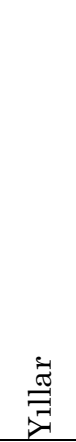 } & \multicolumn{2}{|c|}{$\begin{array}{l}\cdot N \\
\frac{7}{0} \\
\frac{0}{4}\end{array}$} & \multicolumn{2}{|c|}{ 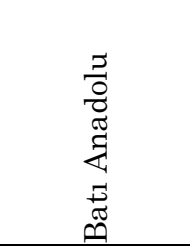 } & \multicolumn{2}{|c|}{ 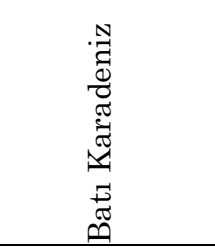 } & \multicolumn{2}{|c|}{ 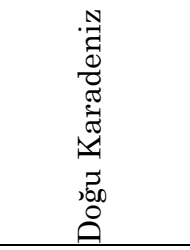 } & \multicolumn{4}{|c|}{ 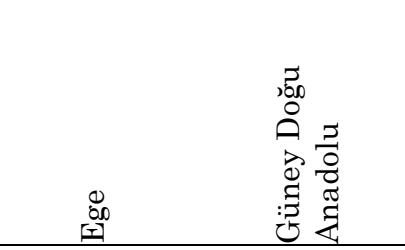 } & \multicolumn{2}{|c|}{ 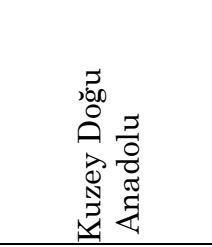 } & \multicolumn{2}{|c|}{ 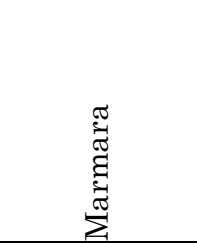 } & \multicolumn{2}{|c|}{ 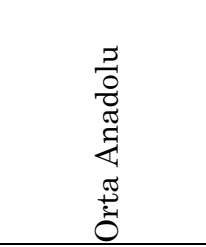 } & \multicolumn{2}{|c|}{ 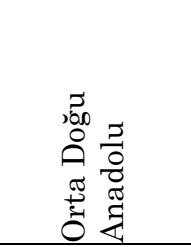 } & \multicolumn{2}{|c|}{ 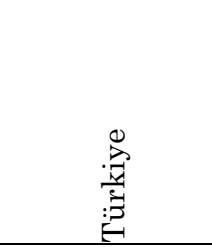 } \\
\hline & 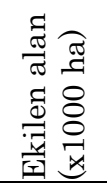 & 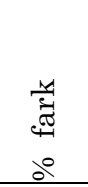 & 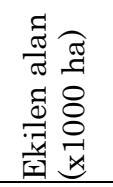 & 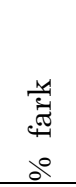 & 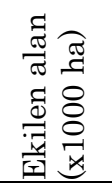 & 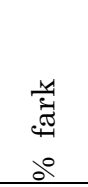 & 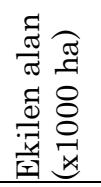 & 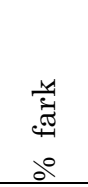 & 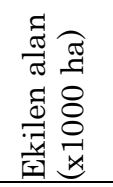 & 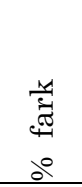 & 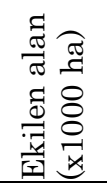 & 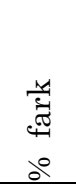 & 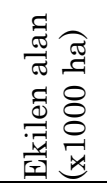 & 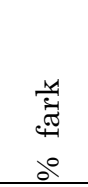 & 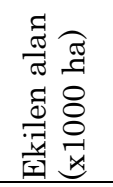 & 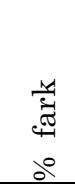 & 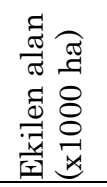 & 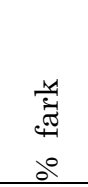 & 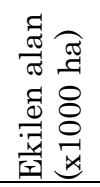 & 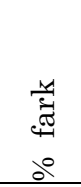 & 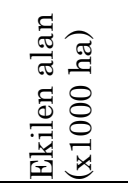 & 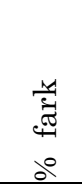 \\
\hline 2010 & 2464.8 & & 3497.3 & & 2126.4 & & 664.5 & & 2839.8 & & 3212.3 & & 1263.9 & & 3043.0 & & 3993.4 & & 1288.8 & & 24394.2 & \\
\hline 2011 & 2388.1 & -3.11 & 3371.3 & -3.60 & 2058.6 & -3.19 & 699.4 & 5.25 & 2752.3 & -3.08 & 3028.3 & -5.73 & 1286.5 & 1.79 & 2980.7 & -2.05 & 3788.1 & -5.14 & 1260.5 & -2.20 & 23613.8 & -3.20 \\
\hline 2012 & 2318.0 & -2.94 & 3380.2 & 0.26 & 2087.5 & 1.40 & 702.8 & 0.49 & 2799.9 & 1.73 & 2980.7 & -1.57 & 1484.9 & 15.42 & 2970.6 & -0.34 & 3786.0 & -0.06 & 1271.4 & 0.86 & 23782.0 & 0.71 \\
\hline 2013 & 2338.5 & 0.88 & 3450.0 & 2.06 & 2050.6 & -1.77 & 675.7 & -3.86 & 2809.5 & 0.34 & 3152.6 & 5.77 & 1297.7 & -12.61 & 3047.3 & 2.58 & 3686.4 & -2.63 & 1297.1 & 2.02 & 23805.5 & 0.10 \\
\hline 2014 & 2354.6 & 0.69 & 3473.1 & 0.67 & 2077.7 & 1.32 & 670.4 & -0.78 & 2784.7 & -0.88 & 3129.1 & -0.75 & 1274.5 & -1.79 & 3112.9 & 2.15 & 3741.4 & 1.49 & 1322.3 & 1.94 & 23940.7 & 0.57 \\
\hline 2015 & 2321.9 & -1.39 & 3486.9 & 0.40 & 2061.2 & -0.79 & 667.8 & -0.39 & 2795.3 & 0.38 & 3110.9 & -0.58 & 1271.4 & -0.24 & 3134.4 & 0.69 & 3774.8 & 0.89 & 1309.0 & -1.01 & 23933.6 & -0.03 \\
\hline 2016 & 2301.6 & -0.87 & 3503.5 & 0.48 & 2031.6 & -1.44 & 663.4 & -0.66 & 2769.5 & -0.92 & 3026.3 & -2.72 & 1242.1 & -2.30 & 3148.6 & 0.45 & 3725.7 & -1.30 & 1298.8 & -0.78 & 23711.2 & -0.93 \\
\hline 2017 & 2273.6 & -1.22 & 3399.2 & -2.98 & 2014.3 & -0.85 & 668.5 & 0.77 & 2757.6 & -0.43 & 2966.6 & -1.97 & 1255.1 & 1.05 & 3131.9 & -0.53 & 3620.9 & -2.81 & 1258.8 & -3.08 & 23346.6 & -1.54 \\
\hline 2018 & 2251.9 & -0.95 & 3407.9 & 0.26 & 1971.2 & -2.14 & 678.8 & 1.54 & 2758.3 & 0.03 & 2912.5 & -1.82 & 1266.3 & 0.89 & 3086.3 & -1.46 & 3609.8 & -0.31 & 1242.6 & -1.29 & 23185.5 & -0.69 \\
\hline 2019 & 2204.0 & -2.13 & 3358.0 & -1.46 & 1997.0 & 1.31 & 666.4 & -1.83 & 2760.0 & 0.06 & 2901.6 & -0.37 & 1280.4 & 1.11 & 3071.5 & -0.48 & 3608.9 & -0.02 & 1247.2 & 0.37 & 23094.9 & -0.39 \\
\hline Ort & & -1.23 & & -0.44 & & -0.68 & & 0.06 & & $\begin{array}{l}-0.31 \\
\end{array}$ & & -1.08 & & 0.37 & & 0.11 & & -1.10 & & -0.35 & & $\begin{array}{l}-0.60 \\
\end{array}$ \\
\hline
\end{tabular}


Çizelge 5. Tarım bölgelerinin 2010-2019 yıllarındaki toplam traktör sayıları

Table 5. Total number of tractors of agricultural regions in 2010-2019
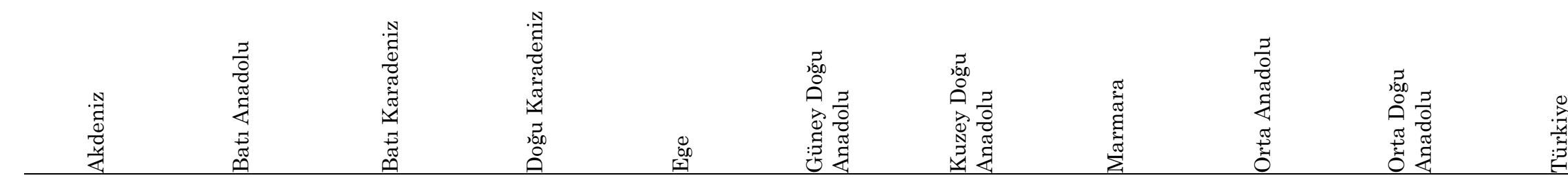

\begin{tabular}{|c|c|c|c|c|c|c|c|c|c|c|c|c|c|c|c|c|c|c|c|c|c|c|}
\hline 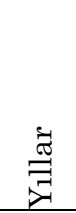 & 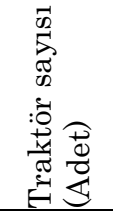 & 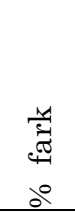 & 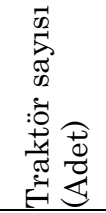 & 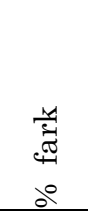 & 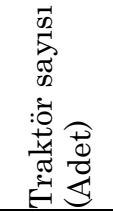 & 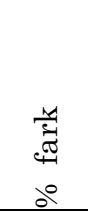 & 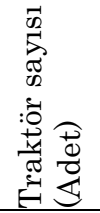 & 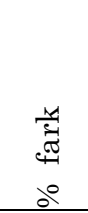 & 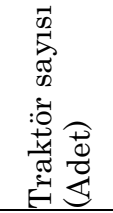 & 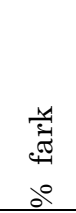 & 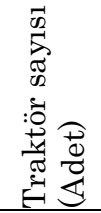 & $\begin{array}{l}\frac{y}{\tilde{z}} \\
d^{\circ} \\
\partial^{\circ}\end{array}$ & 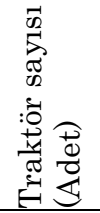 & 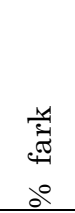 & 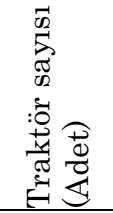 & 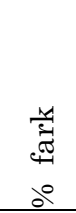 & 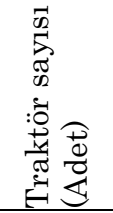 & 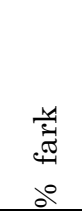 & 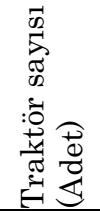 & 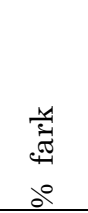 & 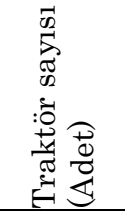 & 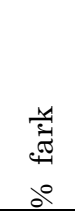 \\
\hline 2010 & 131949 & & 93823 & & 150691 & & 7389 & & 230698 & & 56068 & & 35289 & & 241416 & & 118791 & & 30307 & & 1096421 & \\
\hline 2011 & 136521 & 3.46 & 94866 & 1.11 & 156018 & 3.54 & 9697 & 31.24 & 234462 & 1.63 & 56967 & 1.60 & 37196 & 5.40 & 245446 & 1.67 & 121752 & 2.49 & 31671 & 4.50 & 1124596 & 2.57 \\
\hline 2012 & 148262 & 8.60 & 94375 & -0.52 & 164353 & 5.34 & 10466 & 7.93 & 247565 & 5.59 & 63087 & 10.74 & 37959 & 2.05 & 254473 & 3.68 & 124340 & 2.13 & 32935 & 3.99 & 1177815 & 4.73 \\
\hline 2013 & 151468 & 2.16 & 108325 & 14.78 & 171048 & 4.07 & 12335 & 17.86 & 252014 & 1.80 & 63810 & 1.15 & 39543 & 4.17 & 256211 & 0.68 & 122618 & -1.38 & 35764 & 8.59 & 1213136 & 3.00 \\
\hline 2014 & 157198 & 3.78 & 111823 & 3.23 & 176278 & 3.06 & 13181 & 6.86 & 258933 & 2.75 & 65186 & 2.16 & 40658 & 2.82 & 257282 & 0.42 & 126128 & 2.86 & 36243 & 1.34 & 1242910 & 2.45 \\
\hline 2015 & 159458 & 1.44 & 113411 & 1.42 & 181642 & 3.04 & 13487 & 2.32 & 258992 & 0.02 & 66189 & 1.54 & 41938 & 3.15 & 259074 & 0.70 & 129153 & 2.40 & 36624 & 1.05 & 1259968 & 1.37 \\
\hline 2016 & 161742 & 1.43 & 113589 & 0.16 & 181579 & -0.03 & 14000 & 3.80 & 261494 & 0.97 & 66690 & 0.76 & 42577 & 1.52 & 262720 & 1.41 & 131757 & 2.02 & 37069 & 1.22 & 1273217 & 1.05 \\
\hline 2017 & 165740 & 2.47 & 116190 & 2.29 & 183665 & 1.15 & 14881 & 6.29 & 274251 & 4.88 & 68334 & 2.47 & 46700 & 9.68 & 264412 & 0.64 & 134304 & 1.93 & 37950 & 2.38 & 1306427 & 2.61 \\
\hline 2018 & 168399 & 1.60 & 117312 & 0.97 & 186244 & 1.40 & 15147 & 1.79 & 279795 & 2.02 & 69340 & 1.47 & 48829 & 4.56 & 266798 & 0.90 & 137218 & 2.17 & 42748 & 12.64 & 1331830 & 1.94 \\
\hline 2019 & 171670 & 1.94 & 118194 & 0.75 & 188823 & 1.38 & 15387 & 1.58 & 286717 & 2.47 & 71476 & 3.08 & 51504 & 5.48 & 268238 & 0.54 & 138802 & 1.15 & 43992 & 2.91 & 1354803 & 1.72 \\
\hline Ort & & 2.99 & & 2.69 & & 2.55 & & 8.85 & & 2.46 & & 2.77 & & 4.32 & & 1.18 & & 1.75 & & 4.29 & & 2.38 \\
\hline
\end{tabular}


Çizelge 6. Tarım bölgelerinin 2010-2019 yıllarındaki ortalama traktör gücü (kW) değerleri

Table 6. Average tractor power $(\mathrm{kW})$ values of the agricultural regions in 2010-2019

\begin{tabular}{|c|c|c|c|c|c|c|c|c|c|c|c|c|c|c|c|c|c|c|c|c|c|c|}
\hline & $\frac{a}{2}$ & & 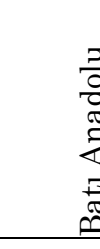 & & $\begin{array}{l}\pi \\
0 \\
0 \\
0\end{array}$ & & & & $\begin{array}{l}80 \\
80 \\
0\end{array}$ & & 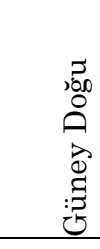 & & 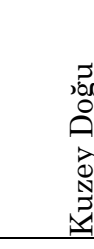 & & $\begin{array}{l}\pi \\
\Sigma \\
\Sigma \\
\Sigma \\
\Sigma \\
\Sigma\end{array}$ & & & & 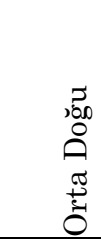 & & & \\
\hline$\underset{\gamma}{\stackrel{\vec{\sigma}}{\rightleftarrows}}$ & 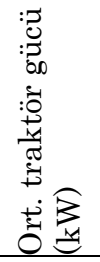 & $\begin{array}{l}\text { त्य } \\
\text { त्ञ } \\
\text { do }\end{array}$ & 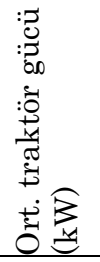 & 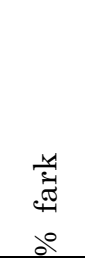 & 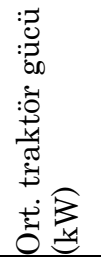 & 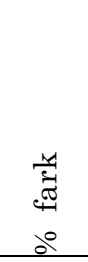 & 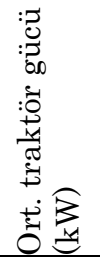 & 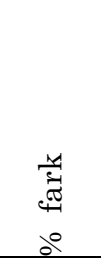 & 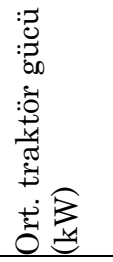 & 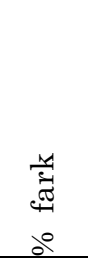 & 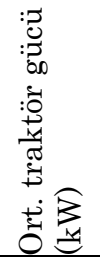 & 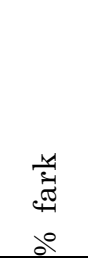 & 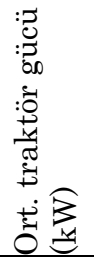 & 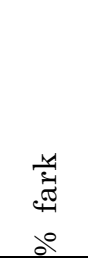 & 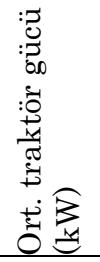 & 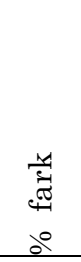 & 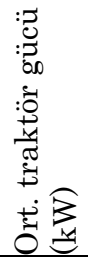 & 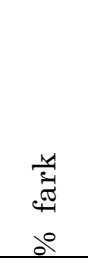 & 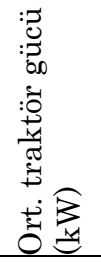 & 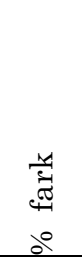 & 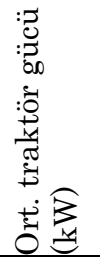 & 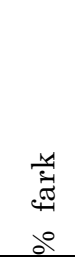 \\
\hline 2010 & 35.38 & & 40.54 & & 34.99 & & 31.24 & & 35.21 & & 39.91 & & 42.78 & & 37.36 & & 38.87 & & 37.86 & & 37.06 & \\
\hline 2011 & 35.20 & -0.51 & 40.55 & 0.02 & 34.67 & -0.91 & 25.65 & -17.89 & 35.11 & -0.28 & 39.85 & -0.15 & 42.78 & 0.00 & 37.26 & -0.27 & 38.78 & -0.23 & 37.48 & -1.00 & 36.87 & -0.51 \\
\hline 2012 & 35.79 & 1.68 & 41.06 & 1.26 & 34.67 & 0.00 & 24.39 & -4.91 & 35.22 & 0.31 & 39.54 & -0.78 & 42.93 & 0.35 & 37.38 & 0.32 & 38.95 & 0.44 & 37.33 & -0.40 & 36.98 & 0.30 \\
\hline 2013 & 35.91 & 0.34 & 41.89 & 2.02 & 34.73 & 0.17 & 20.44 & -16.20 & 35.26 & 0.11 & 39.63 & 0.23 & 43.00 & 0.16 & 37.41 & 0.08 & 39.14 & 0.49 & 37.23 & -0.27 & 37.09 & 0.30 \\
\hline 2014 & 35.63 & -0.78 & 41.73 & -0.38 & 34.09 & -1.84 & 19.60 & -4.11 & 35.11 & -0.43 & 40.04 & 1.03 & 42.92 & -0.19 & 37.45 & 0.11 & 39.64 & 1.28 & 37.13 & -0.27 & 36.98 & -0.30 \\
\hline 2015 & 35.76 & 0.36 & 41.89 & 0.38 & 33.97 & -0.35 & 19.63 & 0.15 & 35.14 & 0.09 & 40.24 & 0.50 & 44.16 & 2.89 & 37.80 & 0.93 & 39.68 & 0.10 & 37.58 & 1.21 & 37.14 & 0.43 \\
\hline 2016 & 35.86 & 0.28 & 41.98 & 0.21 & 33.98 & 0.03 & 19.39 & -1.22 & 35.28 & 0.40 & 40.25 & 0.02 & 44.24 & 0.18 & 37.94 & 0.37 & 39.71 & 0.08 & 37.62 & 0.11 & 37.23 & 0.24 \\
\hline 2017 & 36.08 & 0.61 & 42.42 & 1.05 & 34.21 & 0.68 & 19.18 & -1.08 & 35.61 & 0.94 & 40.40 & 0.37 & 44.73 & 1.11 & 38.12 & 0.47 & 40.05 & 0.86 & 37.67 & 0.13 & 37.49 & 0.70 \\
\hline 2018 & 36.24 & 0.44 & 42.73 & 0.73 & 34.30 & 0.26 & 19.12 & -0.31 & 35.72 & 0.31 & 40.39 & -0.02 & 45.05 & 0.72 & 38.18 & 0.16 & 40.36 & 0.77 & 39.04 & 3.64 & 37.68 & 0.51 \\
\hline 2019 & 36.39 & 0.41 & 43.87 & 2.67 & 34.41 & 0.32 & 18.91 & -1.10 & 35.81 & 0.25 & 40.38 & -0.02 & 45.25 & 0.44 & 38.25 & 0.18 & 40.58 & 0.55 & 39.28 & 0.61 & 37.88 & 0.53 \\
\hline Ort & & 0.32 & & 0.89 & & -0.18 & & -5.19 & & 0.19 & & 0.13 & & 0.63 & & 0.26 & & 0.48 & & 0.42 & & 0.24 \\
\hline
\end{tabular}


Cizelge 7. Tarım bölgelerinin 2010-2019 yıllarındaki toplam traktör gücü (kW) değerleri

Table 7. Total tractor power $(\mathrm{kW})$ values of the agricultural regions in 2010-2019

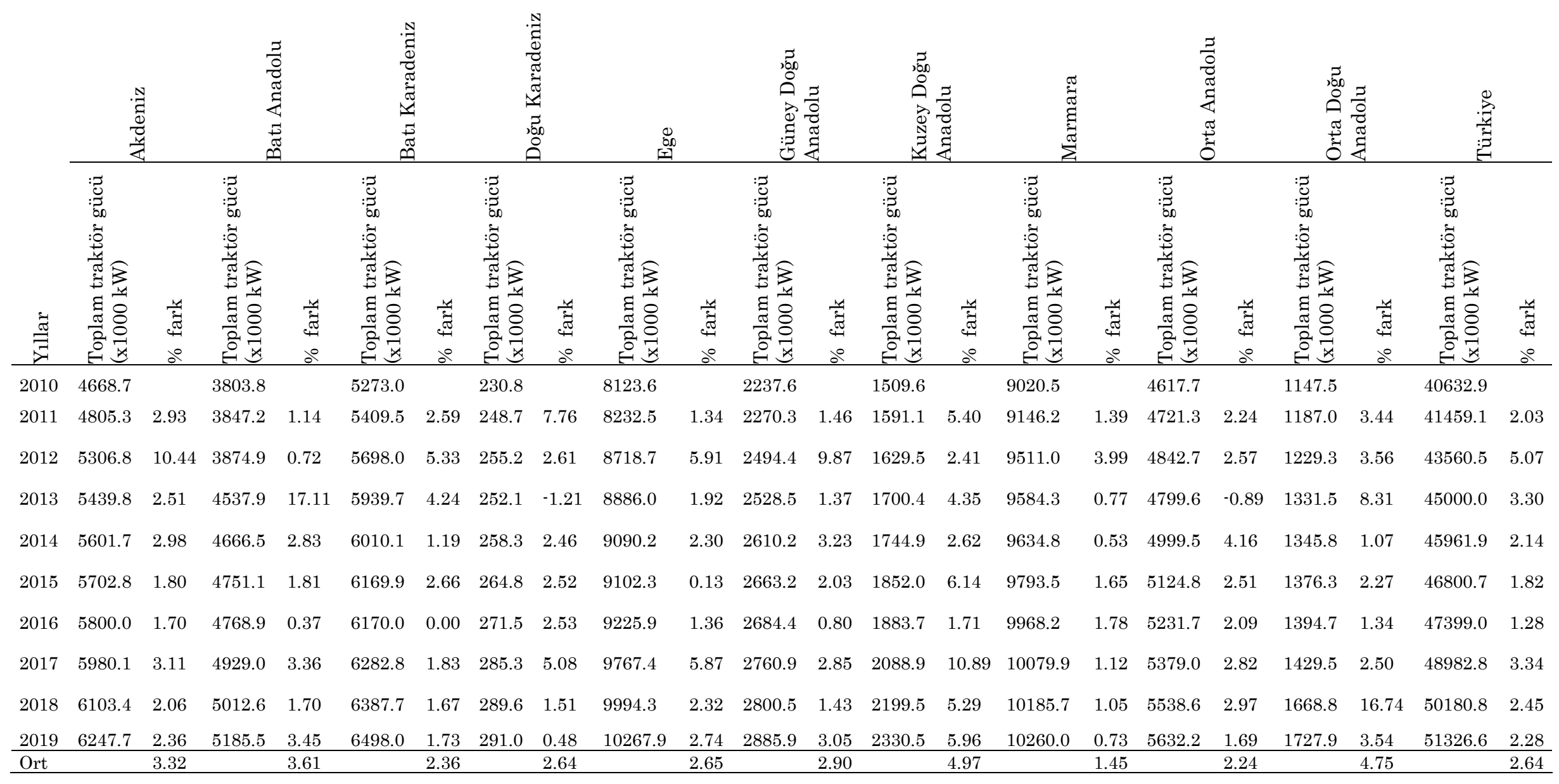


Cizelge 8. Tarım bölgelerinin 2010-2019 yıllarındaki toplam tarım alet/makina sayıları

Table 8. Total agricultural tool/machine numbers of the agricultural regions in 2010-2019

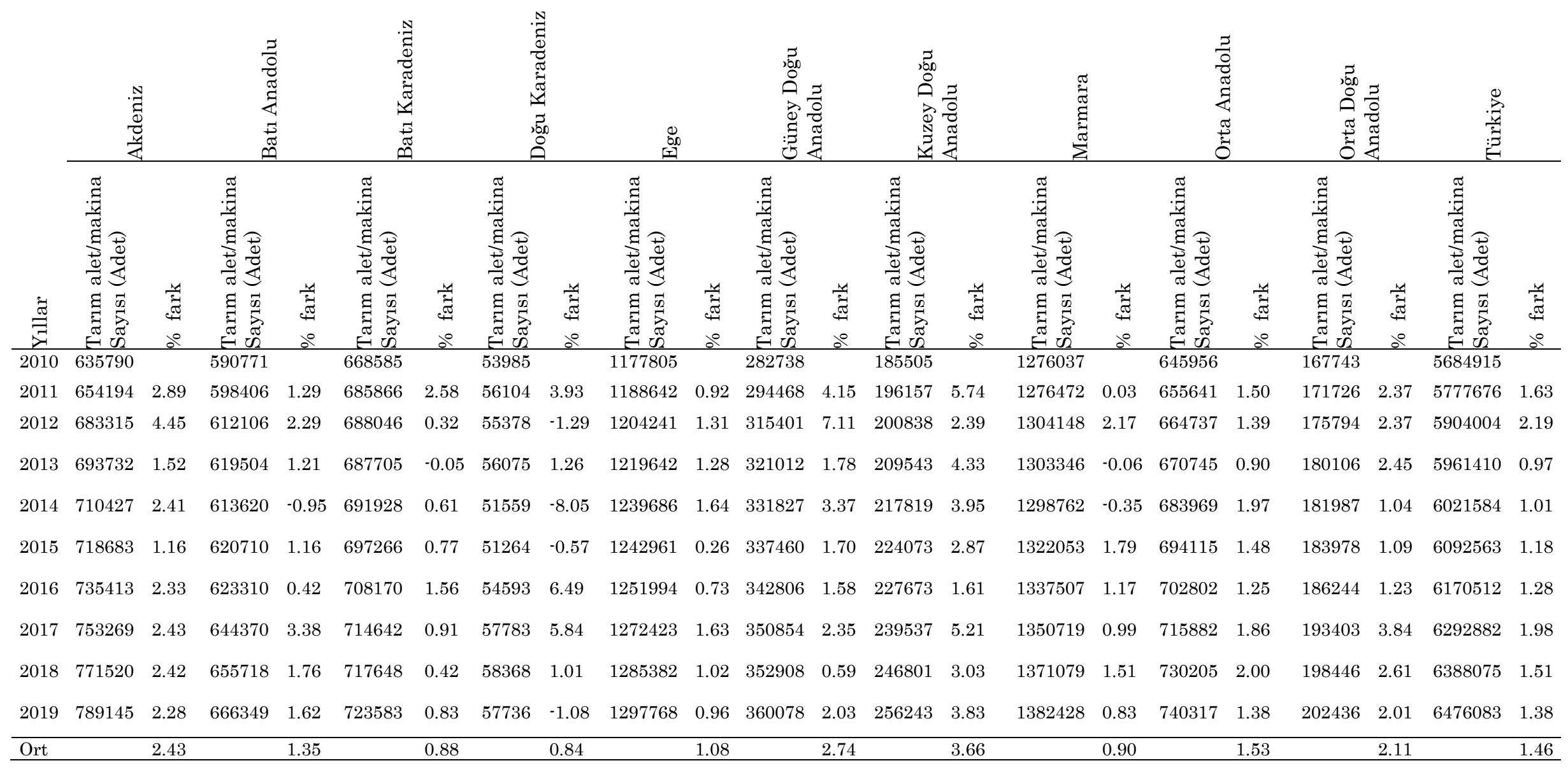


Mekanizasyon düzeyinin belirlenmesinde yaygin olan; birim alana düşen traktör gücü $\left(\mathrm{kW} \mathrm{ha} \mathrm{a}^{-1}\right), 1000$ ha alana düşen traktör sayısı (traktör 1000 ha $^{-1}$ ), bir traktöre düşen toplam alan (ha traktör-1) ve bir traktöre düşen makina sayısı (makina traktör-1) göstergeleri esas alınmıştır. $\mathrm{Bu}$ göstergelerin hesaplanmasında Çizelge 4-8'den yararlanılmıştır.

Elde edilen verilerden Türkiye'nin on tarım bölgesine göre; mekanizasyon düzeyi gösterge değerleri ( $\mathrm{kW}$ ha' 1, traktör 1000 ha $^{-1}$, ha traktör ${ }^{-1}$, makina traktör ${ }^{-1}$ ) belirlenerek çizelgelere ve grafiklere aktarılmış ve değerlendirilmiştir.

Gelecek yıllar (2020-2030) için mekanizasyon düzeyi $\left(\mathrm{kW} \mathrm{ha}^{-1}\right)$ gösterge değerinin tahmin edilmesinde trend analizi kullanılmıştır. Trend (eğilim) analizi bir zaman serisinin uzun dönemdeki ana eğilimi olarak tanımlanan eğilimin bir doğru veya bir eğri ile ifade edilmesidir (Yavuz, 2016). Trend analizinde ele alınan zaman serisini en iyi temsil edecek trend denklemi belirlendikten sonra, gelecek dönem için tahminler elde edilir. Trendin tahmini, en küçük kareler yöntemi, hareketli ortalama ve yarıyıl ortalamalar yöntemi ile yapılabilir (Abdikoğlu, 2019). Bu çalışmada trend eğrisinin denklemini bulmak için en küçük kareler yöntemi kullanılmıştır. Ancak trend eğrisinin denklemini bulmak için en küçük kareler yönteminin farklı denklem türlerinin (doğrusal, logaritmik, üssel, vd.) incelenmesi gerekmektedir (Witt ve Witt, 1992). Bu çalışmada farklı denklem türleri incelenmiş ve determinasyon katsayısı $\left(\mathrm{R}^{2}\right)$ en yüksek olan lineer trend denklemi uygulanarak analiz yapılmıştır.

\section{BULGULAR ve TARTIŞMA}

Türkiye'nin tarım bölgelerinin; 2010-2019 yıllarındaki mekanizasyon düzeyi gösterge değerleri Çizelge 9-12 ve Şekil 1-4'te, 2020-2030 yıllarında trend analizi ile belirlenen işlenen alana düşen traktör gücü $\left(\mathrm{kW} \mathrm{ha}^{-1}\right)$ değerleri ise Çizelge 13 ve Şekil 5 'te verilmiştir.

Son on yılda (2010-2019), işlenen alana düşen traktör gücü ( $\mathrm{kW}$ ha $\left.{ }^{-1}\right)$ değeri; Türkiye'nin on tarım bölgesinde ve Türkiye genelinde yıllara göre artmış ve en yüksek değerler (2.86-3.72 $\mathrm{kW} \mathrm{ha}^{-1}$ ) Ege Bölgesinde, en düşük değerler (0.35-0.44 kW ha $\left.{ }^{-1}\right)$ ise Doğu Karadeniz Bölgesinde gerçekleşmiştir. Türkiye genelinde ise $\mathrm{kW}$ ha ${ }^{-1}$ değeri son on yılda ortalama \%3.22 artış göstermiş ve 1.67-2.22 $\mathrm{kW} \mathrm{ha}^{-1}$ olarak gerçekleşmiştir (Çizelge 9, Şekil 1). Türkiye ve tarım bölgelerinde, işlenen alan başına düşen traktör gücü $\left(\mathrm{kW} \mathrm{ha}^{-1}\right)$ değerlerinin yıllara göre giderek artması, yıllara göre traktör sayısı (Çizelge 5) ve güç değerlerinin (Çizelge 6-7) artması ve az da olsa işlenen tarım alanlarının azalmasından (Çizelge 4) kaynaklanmaktadır. Ayrıca, ekonomik ömrünü dolduran traktörlerin yerine daha yüksek güce sahip traktörlerin satın alınması da işlenen alan başına traktör gücünü arttıran bir faktördür.
Son on yılda, traktör 1000 ha $^{-1}$ değeri; tüm tarım bölgelerinde ve Türkiye genelinde ylllara göre artış göstermiştir (Şekil 2). On yıllık (2010-2019) ortalama artış değerleri \%1.09-8.75 arasında gerçekleşmiştir (Çizelge 10). Traktör $1000 \mathrm{ha}^{-1}$ değerinin artması; yıllara göre traktör sayısının artması (Çizelge 5) ve işlenen tarım alanlarının azalmasından (Çizelge 4) kaynaklanmaktadir.

On ylllık (2010-2019) zaman sürecinde, ha traktör-1 değeri; tüm tarım bölgeleri ve Türkiye genelinde azalma göstermiştir (Şekil 3). On yıllık ortalama azalma; en fazla Doğu Karadeniz Bölgesinde (-\%7.56), en az Marmara Bölgesinde (-\%1.04) gerçekleşmiştir. Türkiye'de ortalama azalma değeri ise -\%2.91 olmuştur (Çizelge 11). ha traktör ${ }^{-1}$ değerindeki azalma, mekanizasyon düzeyinin arttığı veya iyileştiğinin bir ifadesidir.

Türkiye'nin ve tarım bölgelerinin, 2010-2019 yıllarında traktör başına düşen alet/makina sayısı (makina traktör-1); azalmıştır (Şekil 4). On yıllık ortalama azalma; en fazla Doğu Karadeniz Bölgesinde (-\%6.84), en az Güney Doğu Anadolu Bölgesinde (\%0.01) gerçekleşmiştir. Türkiye'de ortalama azalma değeri ise $\% 0.89$ olmuştur (Çizelge 12). Makina traktör ${ }^{-1}$ oranındaki azalma; on yıllık süreçte makina sayılarındaki artış oranlarının (Çizelge 8) traktör sayılarındaki artış oranlarından (Çizelge 5) daha az olmasindan kaynaklanmaktadir.

2010 yılı verilerine göre AB'de 1 ha üretim alanına düşen traktör gücü $6 \mathrm{~kW}$, traktör başına düşen üretim alanı 11.30 ha, 1000 ha tarım alanına düşen traktör sayısı 89, traktör başına düşen makina sayısı ise 10'dur (İleri, 2010; Gökdoğan 2012). Bu rakamlar Türkiye'nin tarımsal mekanizasyon düzeyinin geçen on yıllık süreçteki tüm gelişmelere rağmen hala yeterli düzeyde olmadığını göstermektedir.

Türkiye'nin ve tarım bölgelerinin gelecek yıllar (20202030) için mekanizasyon gösterge değerlerinden, işlenen alana düşen traktör gücü $\left(\mathrm{kW} \mathrm{ha}^{-1}\right)$ değerlerinin belirlenmesi için 2010-2019 yıllarındaki $\mathrm{kW} \mathrm{ha}^{-1}$ değerlerinin değişiminden trend analizi yardımıyla tahmin edilmiştir. Buna göre $\mathrm{kW}$ ha ${ }^{-1}$ değeri; tüm tarım bölgelerinde ve Türkiye genelinde gelecek yıllara göre artış olacağı beklenmektedir (Şekil 5). Gelecek on bir ylllık (2020-2030) ortalama artış değerleri \%0.89-3.18 arasında gerçekleşeceği öngörülmektedir. $\mathrm{kW}$ ha-1 değeri; Türkiye geneli için 2020 yilında $2.27,2025$ yilinda 2.55 ve 2030 yilında 2.84 olması tahmin edilmektedir (Çizelge 13).

\section{SONUÇ ve ÖNERILLER}

$\mathrm{Bu}$ çalışmada, tarımsal mekanizasyon planlamalarında; etkinliği arttırma ve yön vermede katkı sağlayacağ bölgesinin, son 10 yıla (2010-2019) ait tarımsal mekanizasyon düzeyi gösterge değerleri (traktör sayısı 
Çizelge 9. Türkiye'nin tarım bölgelerinin 2010-2019 yıllarında işlenen alana düşen traktör gücü (kW ha-1)

Table 9. Tractor power per unit cultivated area $\left(\mathrm{kW} \mathrm{ha}^{-1}\right)$ of the Turkey's agricultural regions in 2010-2019

\begin{tabular}{|c|c|c|c|c|c|c|c|c|c|c|c|c|c|c|c|c|c|c|c|c|c|c|}
\hline & & & & & & & & & \begin{tabular}{c}
0 \\
0 \\
\multicolumn{1}{c}{}
\end{tabular} & & & & & & & & & & \multicolumn{2}{|c|}{ 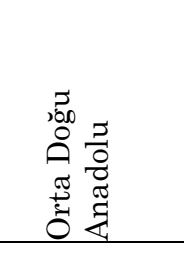 } & \multicolumn{2}{|c|}{ 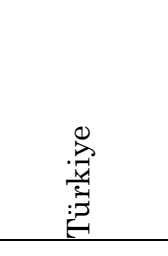 } \\
\hline$\underset{\nexists}{\stackrel{\sigma}{\Xi}}$ & $\sum_{\pi}^{3}$ & 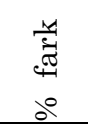 & $\sum_{\pi}^{\pi}$ & 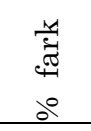 & 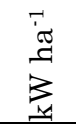 & $\begin{array}{l}\underset{\tilde{a}}{\tilde{a}} \\
\partial^{\circ}\end{array}$ & $\sum_{\sqrt{\pi}}$ & 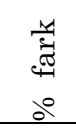 & 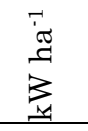 & 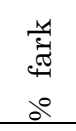 & $\sum_{\pi}^{3}$ & 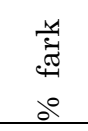 & 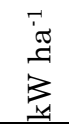 & 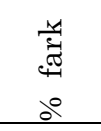 & $\begin{array}{l}\vec{\sigma} \\
\vec{\pi} \\
\sum_{\pi}\end{array}$ & 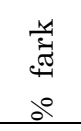 & ${ }_{i}^{-1}$ & $\begin{array}{l}\text { तै } \\
\tilde{\pi} \\
\partial^{\circ}\end{array}$ & $\sum_{\pi}^{3}$ & 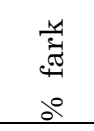 & $\sum_{\pi}^{\vec{\sigma}}$ & 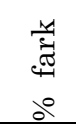 \\
\hline 2010 & 1.89 & & 1.09 & & 2.48 & & 0.35 & & 2.86 & & 0.70 & & 1.19 & & 2.96 & & 1.16 & & 0.89 & & 1.67 & \\
\hline 2011 & 2.01 & 6.35 & 1.14 & 4.59 & 2.63 & 6.05 & 0.36 & 2.86 & 2.99 & 4.55 & 0.75 & 7.14 & 1.24 & 4.20 & 3.07 & 3.72 & 1.25 & 7.76 & 0.94 & 5.62 & 1.76 & 5.39 \\
\hline 2012 & 2.29 & 13.93 & 1.15 & 0.88 & 2.73 & 3.80 & 0.36 & 0.00 & 3.11 & 4.01 & 0.84 & 12.00 & 1.10 & -11.29 & 3.20 & 4.23 & 1.28 & 2.40 & 0.97 & 3.19 & 1.83 & 3.98 \\
\hline 2013 & 2.33 & 1.75 & 1.32 & 14.78 & 2.90 & 6.23 & 0.37 & 2.78 & 3.16 & 1.61 & 0.80 & -4.76 & 1.31 & 19.09 & 3.15 & -1.56 & 1.30 & 1.56 & 1.03 & 6.19 & 1.89 & 3.28 \\
\hline 2014 & 2.38 & 2.15 & 1.34 & 1.52 & 2.89 & -0.34 & 0.39 & 5.41 & 3.26 & 3.16 & 0.83 & 3.75 & 1.37 & 4.58 & 3.10 & -1.59 & 1.34 & 3.08 & 1.02 & -0.97 & 1.92 & 1.59 \\
\hline 2015 & 2.46 & 3.36 & 1.36 & 1.49 & 2.99 & 3.46 & 0.40 & 2.56 & 3.26 & 0.00 & 0.86 & 3.61 & 1.46 & 6.57 & 3.12 & 0.65 & 1.36 & 1.49 & 1.05 & 2.94 & 1.96 & 2.08 \\
\hline 2016 & 2.52 & 2.44 & 1.36 & 0.00 & 3.04 & 1.67 & 0.41 & 2.50 & 3.33 & 2.15 & 0.89 & 3.49 & 1.52 & 4.11 & 3.17 & 1.60 & 1.40 & 2.94 & 1.07 & 1.90 & 2.00 & 2.04 \\
\hline 2017 & 2.63 & 4.37 & 1.45 & 6.62 & 3.12 & 2.63 & 0.43 & 4.88 & 3.54 & 6.31 & 0.93 & 4.49 & 1.66 & 9.21 & 3.22 & 1.58 & 1.49 & 6.43 & 1.14 & 6.54 & 2.10 & 5.00 \\
\hline 2018 & 2.71 & 3.04 & 1.47 & 1.38 & 3.24 & 3.85 & 0.43 & 0.00 & 3.62 & 2.26 & 0.96 & 3.23 & 1.74 & 4.82 & 3.30 & 2.48 & 1.53 & 2.68 & 1.34 & 17.54 & 2.16 & 2.86 \\
\hline 2019 & 2.83 & 4.43 & 1.54 & 4.76 & 3.25 & 0.31 & 0.44 & 2.33 & 3.72 & 2.76 & 0.99 & 3.13 & 1.82 & 4.60 & 3.34 & 1.21 & 1.56 & 1.96 & 1.39 & 3.73 & 2.22 & 2.78 \\
\hline Ort & & 4.65 & & 4.00 & & 3.07 & & 2.59 & & 2.98 & & 4.01 & & 5.10 & & 1.37 & & 3.37 & & 5.19 & & 3.22 \\
\hline
\end{tabular}


Cizelge 10. Türkiye'nin tarım bölgelerinin 2010-2019 yıllarında 1000 ha alana düşen traktör sayısı (traktör $1000 \mathrm{ha}^{-1}$ )

Table 10. Number of tractors per 1000 ha areas (tractor $1000 \mathrm{ha}^{-1}$ ) of the Turkey's agricultural regions in 2010-2019

\begin{tabular}{|c|c|c|c|c|c|c|c|c|c|c|c|c|c|c|c|c|c|c|c|c|c|c|}
\hline & 8 & & 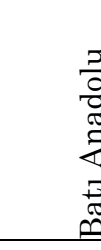 & & $\begin{array}{l}0 \\
0 \\
0 \\
0 \\
0\end{array}$ & & 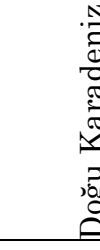 & & $\begin{array}{r}\infty \\
50 \\
\text { r }\end{array}$ & & $\begin{array}{l}5 \\
0 \\
0 \\
0 \\
0 \\
0 \\
0 \\
0 \\
0\end{array}$ & & 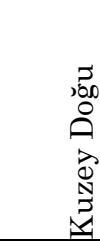 & & స్ & & 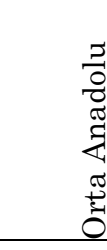 & & 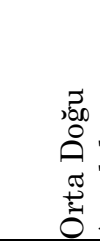 & & 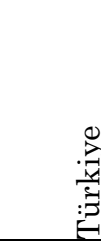 & \\
\hline$\underset{\nexists}{\stackrel{\Xi}{\Xi}}$ & 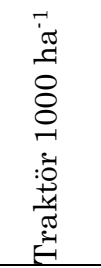 & 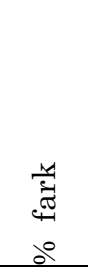 & 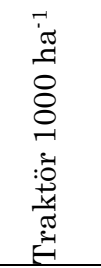 & 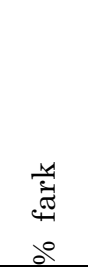 & 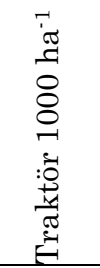 & 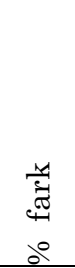 & 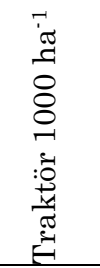 & 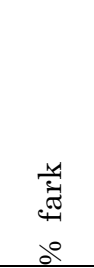 & 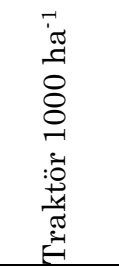 & 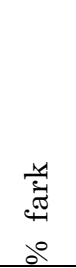 & 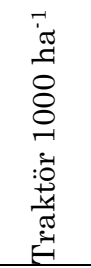 & 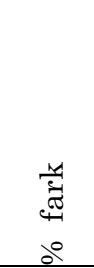 & 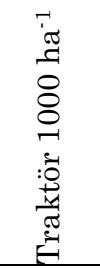 & $\begin{array}{l}\text { चै } \\
\text { ॠँ } \\
\partial^{\circ}\end{array}$ & 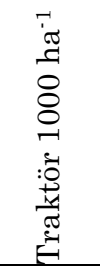 & 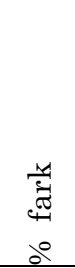 & 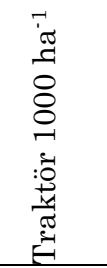 & 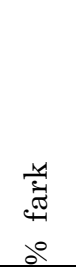 & 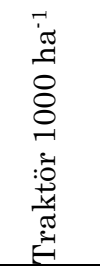 & 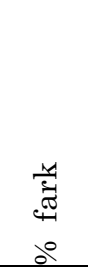 & 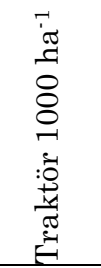 & 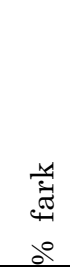 \\
\hline 2010 & 53.53 & & 26.83 & & 70.87 & & 11.12 & & 81.24 & & 17.45 & & 27.92 & & 79.33 & & 29.75 & & 23.52 & & 44.95 & \\
\hline 2011 & 57.17 & 6.80 & 28.14 & 4.88 & 75.79 & 6.94 & 13.87 & 24.73 & 85.19 & 4.86 & 18.81 & 7.79 & 28.91 & 3.55 & 82.34 & 3.79 & 32.14 & 8.03 & 25.13 & 6.85 & 47.62 & 5.94 \\
\hline 2012 & 63.96 & 11.88 & 27.92 & -0.78 & 78.73 & 3.88 & 14.89 & 7.35 & 88.42 & 3.79 & 21.17 & 12.55 & 25.56 & -11.59 & 85.66 & 4.03 & 32.84 & 2.18 & 25.90 & 3.06 & 49.53 & 4.01 \\
\hline 2013 & 64.77 & 1.27 & 31.40 & 12.46 & 83.41 & 5.94 & 18.25 & 22.57 & 89.70 & 1.45 & 20.24 & -4.39 & 30.47 & 19.21 & 84.08 & -1.84 & 33.26 & 1.28 & 27.57 & 6.45 & 50.96 & 2.89 \\
\hline 2014 & 66.76 & 3.07 & 32.20 & 2.55 & 84.84 & 1.71 & 19.66 & 7.73 & 92.98 & 3.66 & 20.83 & 2.92 & 31.90 & 4.69 & 82.65 & -1.70 & 33.71 & 1.35 & 27.41 & -0.58 & 51.92 & 1.88 \\
\hline 2015 & 68.67 & 2.86 & 32.52 & 0.99 & 88.13 & 3.88 & 20.20 & 2.75 & 92.65 & -0.35 & 21.28 & 2.16 & 32.99 & 3.42 & 82.66 & 0.01 & 34.21 & 1.48 & 27.98 & 2.08 & 52.64 & 1.39 \\
\hline 2016 & 70.27 & 2.33 & 32.42 & -0.31 & 89.38 & 1.42 & 21.10 & 4.46 & 94.42 & 1.91 & 22.04 & 3.57 & 34.28 & 3.91 & 83.44 & 0.94 & 35.36 & 3.36 & 28.54 & 2.00 & 53.70 & 2.01 \\
\hline 2017 & 72.90 & 3.74 & 34.18 & 5.43 & 91.18 & 2.01 & 22.26 & 5.50 & 99.45 & 5.33 & 23.03 & 4.49 & 37.21 & 8.55 & 84.43 & 1.19 & 37.09 & 4.89 & 30.15 & 5.64 & 55.96 & 4.21 \\
\hline 2018 & 74.78 & 2.58 & 34.42 & 0.70 & 94.48 & 3.62 & 22.32 & 0.27 & 101.44 & 2.00 & 23.81 & 3.39 & 38.56 & 3.63 & 86.45 & 2.39 & 38.01 & 2.48 & 34.40 & 14.10 & 57.44 & 2.64 \\
\hline 2019 & 77.89 & 4.16 & 35.20 & 2.27 & 94.56 & 0.08 & 23.09 & 3.45 & 103.88 & 2.41 & 24.63 & 3.44 & 40.23 & 4.33 & 87.33 & 1.02 & 38.46 & 1.18 & 35.27 & 2.53 & 58.66 & 2.12 \\
\hline Ort & & 4.30 & & 3.13 & & 3.28 & & 8.75 & & 2.78 & & 3.99 & & 4.41 & & 1.09 & & 2.92 & & 4.68 & & 3.01 \\
\hline
\end{tabular}


Çizelge 11. Türkiye'nin tarım bölgelerinin 2010-2019 yıllarında traktör başına düşen üretim alanı (ha traktör-1)

Table 11. Production area per tractor (ha tractor ${ }^{-1}$ ) value of the Turkey's agricultural regions in 2010-2019

\begin{tabular}{|c|c|c|c|c|c|c|c|c|c|c|c|c|c|c|c|c|c|c|c|c|c|c|}
\hline & 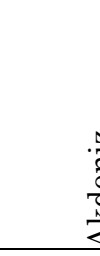 & & 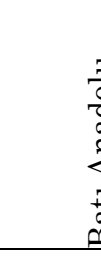 & & 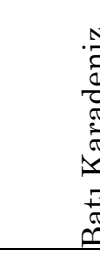 & & & & $\begin{array}{c}0 \\
0 \\
\text { I }\end{array}$ & & 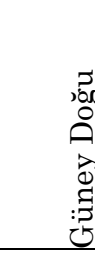 & & & & 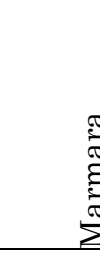 & & $\begin{array}{l}z \\
\frac{7}{c} \\
\frac{1}{4} \\
\frac{\pi}{4} \\
\frac{\pi}{b}\end{array}$ & & & 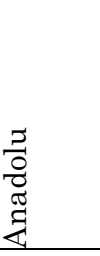 & 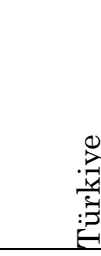 & \\
\hline$\underset{\forall}{\stackrel{\Xi}{\Xi}}$ & 告 & 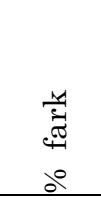 & 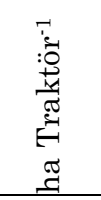 & 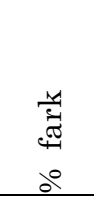 & 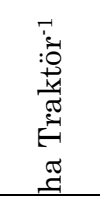 & 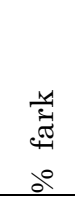 & 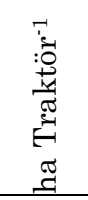 & 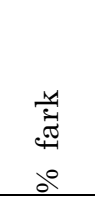 & 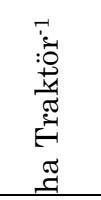 & 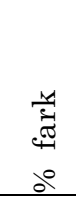 & 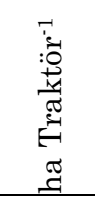 & 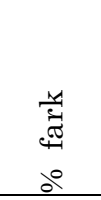 & 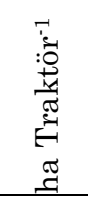 & 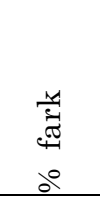 & 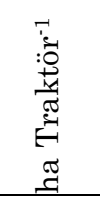 & 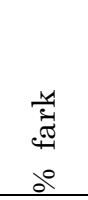 & 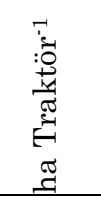 & 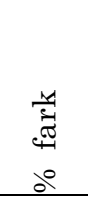 & 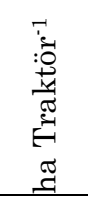 & 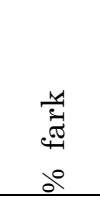 & 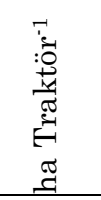 & 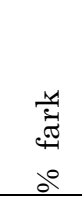 \\
\hline 2010 & 18.68 & & 37.28 & & 14.11 & & 89.93 & & 12.31 & & 57.29 & & 35.82 & & 12.60 & & 33.62 & & 42.53 & & 22.25 & \\
\hline 2011 & 17.49 & -6.37 & 35.54 & -4.67 & 13.19 & -6.52 & 72.12 & -19.80 & 11.74 & -4.63 & 53.16 & -7.21 & 34.59 & -3.43 & 12.14 & -3.65 & 31.11 & -7.47 & 39.80 & -6.42 & 21.00 & -5.62 \\
\hline 2012 & 15.63 & -10.63 & 35.82 & 0.79 & 12.70 & -3.71 & 67.15 & -6.89 & 11.31 & -3.66 & 47.25 & -11.12 & 39.12 & 13.10 & 11.67 & -3.87 & 30.45 & -2.12 & 38.60 & -3.02 & 20.19 & -3.86 \\
\hline 2013 & 15.44 & -1.22 & 31.85 & -11.08 & 11.99 & -5.59 & 54.78 & -18.42 & 11.15 & -1.41 & 49.41 & 4.57 & 32.82 & -16.10 & 11.89 & 1.89 & 30.06 & -1.28 & 36.27 & -6.04 & 19.62 & -2.82 \\
\hline 2014 & 14.98 & -2.98 & 31.06 & -2.48 & 11.79 & -1.67 & 50.86 & -7.16 & 10.75 & -3.59 & 48.00 & -2.85 & 31.35 & -4.48 & 12.10 & 1.77 & 29.66 & -1.33 & 36.48 & 0.58 & 19.26 & -1.83 \\
\hline 2015 & 14.56 & -2.80 & 30.75 & -1.00 & 11.35 & -3.73 & 49.51 & -2.65 & 10.79 & 0.37 & 47.00 & -2.08 & 30.32 & -3.29 & 12.10 & 0.00 & 29.23 & -1.45 & 35.74 & -2.03 & 19.00 & -1.35 \\
\hline 2016 & 14.23 & -2.27 & 30.84 & 0.29 & 11.19 & -1.41 & 47.39 & -4.28 & 10.59 & -1.85 & 45.38 & -3.45 & 29.17 & -3.79 & 11.98 & -0.99 & 28.28 & -3.25 & 35.04 & -1.96 & 18.62 & -2.00 \\
\hline 2017 & 13.72 & -3.58 & 29.26 & -5.12 & 10.97 & -1.97 & 44.92 & -5.21 & 10.06 & -5.00 & 43.41 & -4.34 & 26.88 & -7.85 & 11.84 & -1.17 & 26.96 & -4.67 & 33.17 & -5.34 & 17.87 & -4.03 \\
\hline 2018 & 13.37 & -2.55 & 29.05 & -0.72 & 10.58 & -3.56 & 44.81 & -0.24 & 9.86 & -1.99 & 42.00 & -3.25 & 25.93 & -3.53 & 11.57 & -2.28 & 26.31 & -2.41 & 29.07 & -12.36 & 17.41 & -2.57 \\
\hline 2019 & 12.84 & -3.96 & 28.41 & -2.20 & 10.58 & 0.00 & 43.31 & -3.35 & 9.63 & -2.33 & 40.60 & -3.33 & 24.86 & -4.13 & 11.45 & -1.04 & 26.00 & -1.18 & 28.35 & -2.48 & 17.05 & -2.07 \\
\hline Ort & & -4.04 & & -2.91 & & -3.13 & & -7.56 & & -2.68 & & -3.67 & & $\begin{array}{l}-3.72 \\
\end{array}$ & & -1.04 & & -2.80 & & -4.34 & & -2.91 \\
\hline
\end{tabular}


Çizelge 12. Türkiye'nin tarım bölgelerinin 2010-2019 yıllarında traktör başına düşen alet/makina sayısı (makina traktör-1)

Table 12. Number of tools/machines per tractor (machine tractor ${ }^{-1}$ ) value of the Turkey's agricultural regions in 2010-2019

\begin{tabular}{|c|c|c|c|c|c|c|c|c|c|c|c|c|c|c|c|c|c|c|c|c|c|c|}
\hline & & है & & 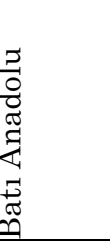 & & & & 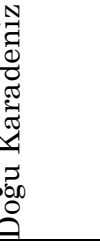 & & & & 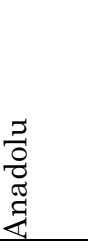 & & & & & & & \multicolumn{2}{|c|}{ 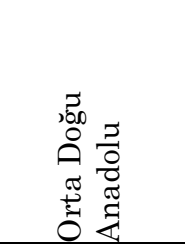 } & \multicolumn{2}{|c|}{ 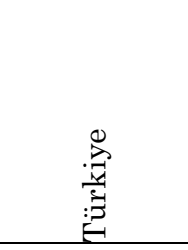 } \\
\hline$\underset{\tilde{\sigma}}{\stackrel{\tilde{\sigma}}{\Xi}}$ & 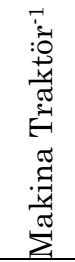 & 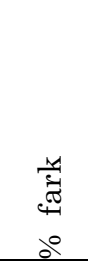 & 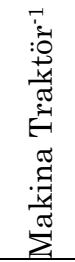 & 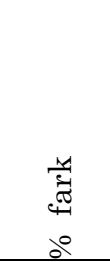 & 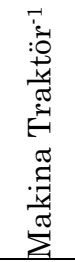 & 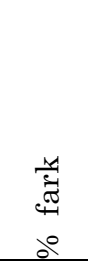 & 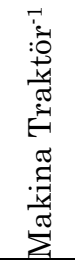 & 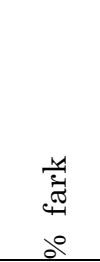 & 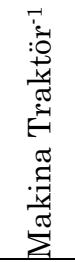 & 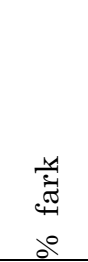 & 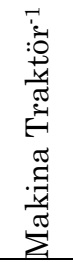 & 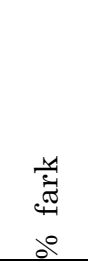 & 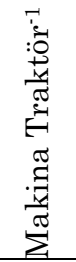 & 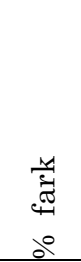 & 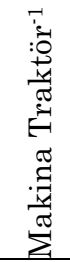 & 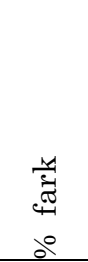 & 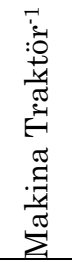 & 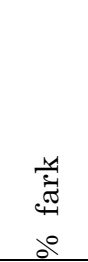 & 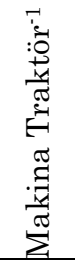 & 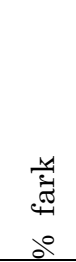 & 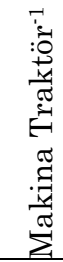 & 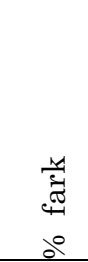 \\
\hline 2010 & 4.82 & & 6.30 & & 4.44 & & 7.31 & & 5.11 & & 5.04 & & 5.26 & & 5.29 & & 5.44 & & 5.53 & & 5.18 & \\
\hline 2011 & 4.79 & -0.62 & 6.31 & 0.16 & 4.40 & -0.90 & 5.79 & -20.79 & 5.07 & -0.78 & 5.17 & 2.58 & 5.27 & 0.19 & 5.20 & -1.70 & 5.39 & -0.92 & 5.42 & -1.99 & 5.14 & -0.77 \\
\hline 2012 & 4.61 & -3.76 & 6.49 & 2.85 & 4.19 & -4.77 & 5.29 & -8.64 & 4.86 & -4.14 & 5.00 & -3.29 & 5.29 & 0.38 & 5.12 & -1.54 & 5.35 & -0.74 & 5.34 & -1.48 & 5.01 & -2.53 \\
\hline 2013 & 4.58 & -0.65 & 5.72 & -11.86 & 4.02 & -4.06 & 4.55 & -13.99 & 4.84 & -0.41 & 5.03 & 0.60 & 5.30 & 0.19 & 5.09 & -0.59 & 5.47 & 2.24 & 5.04 & -5.62 & 4.91 & -2.00 \\
\hline 2014 & 4.52 & -1.31 & 5.49 & -4.02 & 3.93 & -2.24 & 3.91 & -14.07 & 4.79 & -1.03 & 5.09 & 1.19 & 5.36 & 1.13 & 5.05 & -0.79 & 5.42 & -0.91 & 5.02 & -0.40 & 4.84 & -1.43 \\
\hline 2015 & 4.51 & -0.22 & 5.47 & -0.36 & 3.84 & -2.29 & 3.80 & -2.81 & 4.80 & 0.21 & 5.10 & 0.20 & 5.34 & -0.37 & 5.10 & 0.99 & 5.37 & -0.92 & 5.02 & 0.00 & 4.84 & 0.00 \\
\hline 2016 & 4.55 & 0.89 & 5.49 & 0.37 & 3.90 & 1.56 & 3.90 & 2.63 & 4.79 & -0.21 & 5.14 & 0.78 & 5.35 & 0.19 & 5.09 & -0.20 & 5.33 & -0.74 & 5.02 & 0.00 & 4.85 & 0.21 \\
\hline 2017 & 4.54 & -0.22 & 5.55 & 1.09 & 3.89 & -0.26 & 3.88 & -0.51 & 4.64 & -3.13 & 5.13 & -0.19 & 5.13 & -4.11 & 5.11 & 0.39 & 5.33 & 0.00 & 5.10 & 1.59 & 4.82 & -0.62 \\
\hline 2018 & 4.58 & 0.88 & 5.59 & 0.72 & 3.85 & -1.03 & 3.85 & -0.77 & 4.59 & -1.08 & 5.09 & -0.78 & 5.05 & -1.56 & 5.14 & 0.59 & 5.32 & -0.19 & 4.64 & -9.02 & 4.80 & -0.41 \\
\hline 2019 & 4.60 & 0.44 & 5.64 & 0.89 & 3.83 & -0.52 & 3.75 & -2.60 & 4.53 & -1.31 & 5.04 & -0.98 & 4.98 & -1.39 & 5.15 & 0.19 & 5.33 & 0.19 & 4.60 & -0.86 & 4.78 & -0.42 \\
\hline Ort & & -0.51 & & -1.13 & & -1.61 & & -6.84 & & -1.32 & & 0.01 & & -0.59 & & -0.29 & & -0.22 & & -1.97 & & -0.89 \\
\hline
\end{tabular}




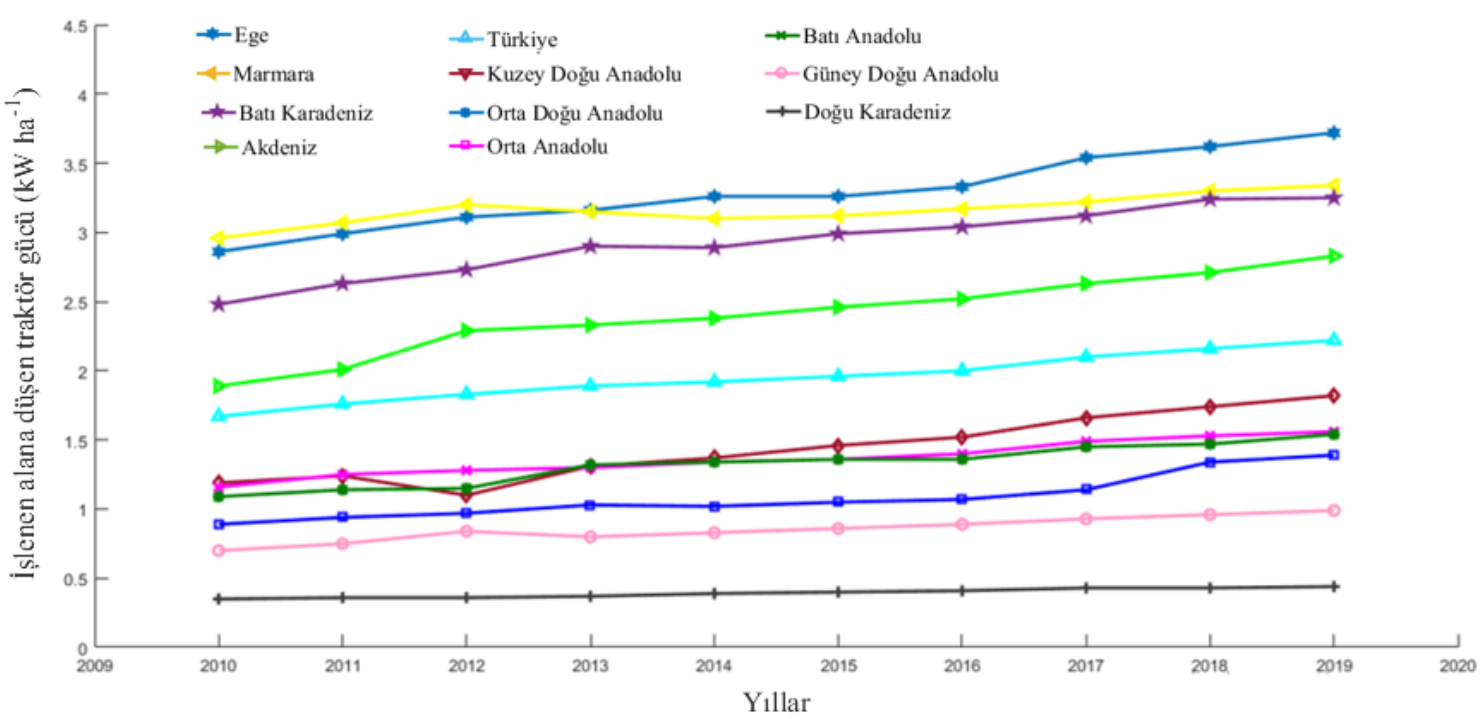

Şekil 1. Türkiye'nin tarım bölgelerinin 2010-2019 yıllarında işlenen alana düşen traktör gücü $\left(\mathrm{kW} \mathrm{ha}^{-1}\right)$

Figure 1. Tractor power per unit cultivated area $\left(\mathrm{kW} \mathrm{ha}^{-1}\right)$ of the Turkey's agricultural regions in 2010-2019

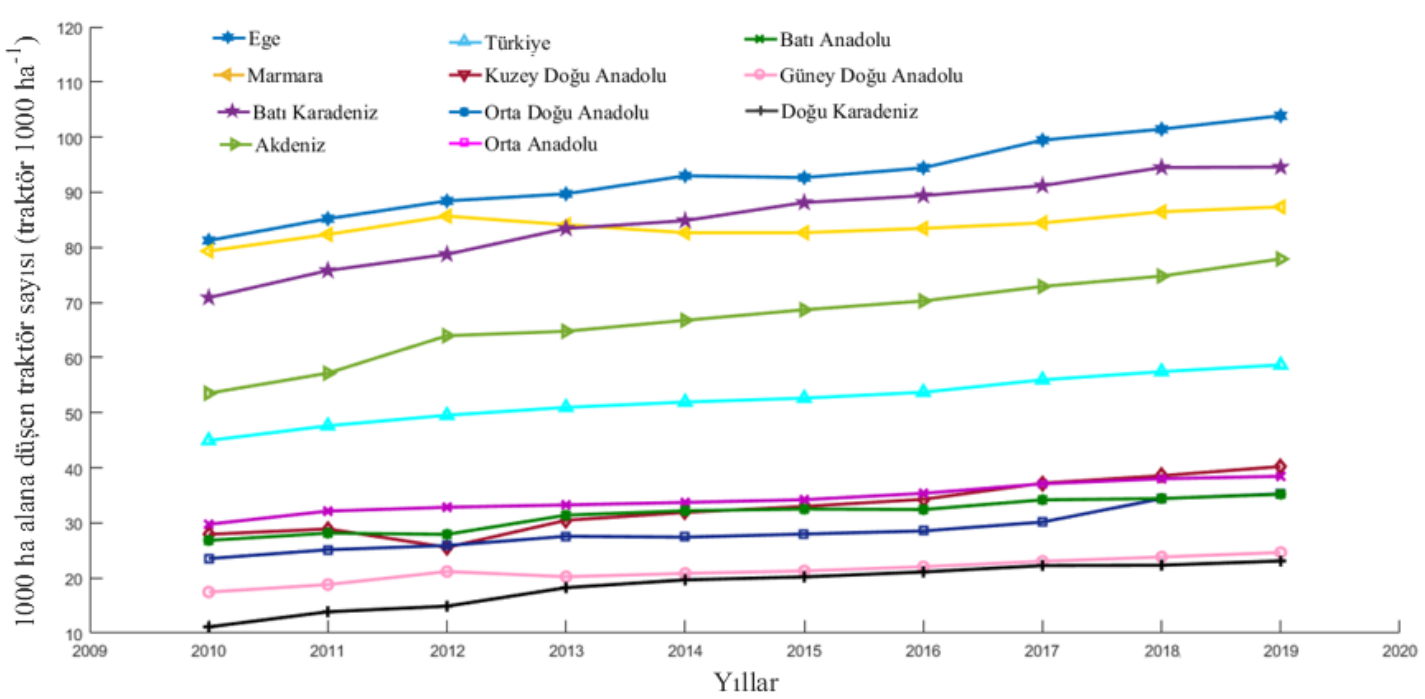

Şekil 2. Türkiye'nin tarım bölgelerinin 2010-2019 yıllarında 1000 ha alana düşen traktör sayısı (traktör 1000ha-1) Figure 2. Number of tractors per 1000 ha areas (tractor $1000 \mathrm{ha}^{-1}$ ) of the Turkey's agricultural regions in 2010-2019

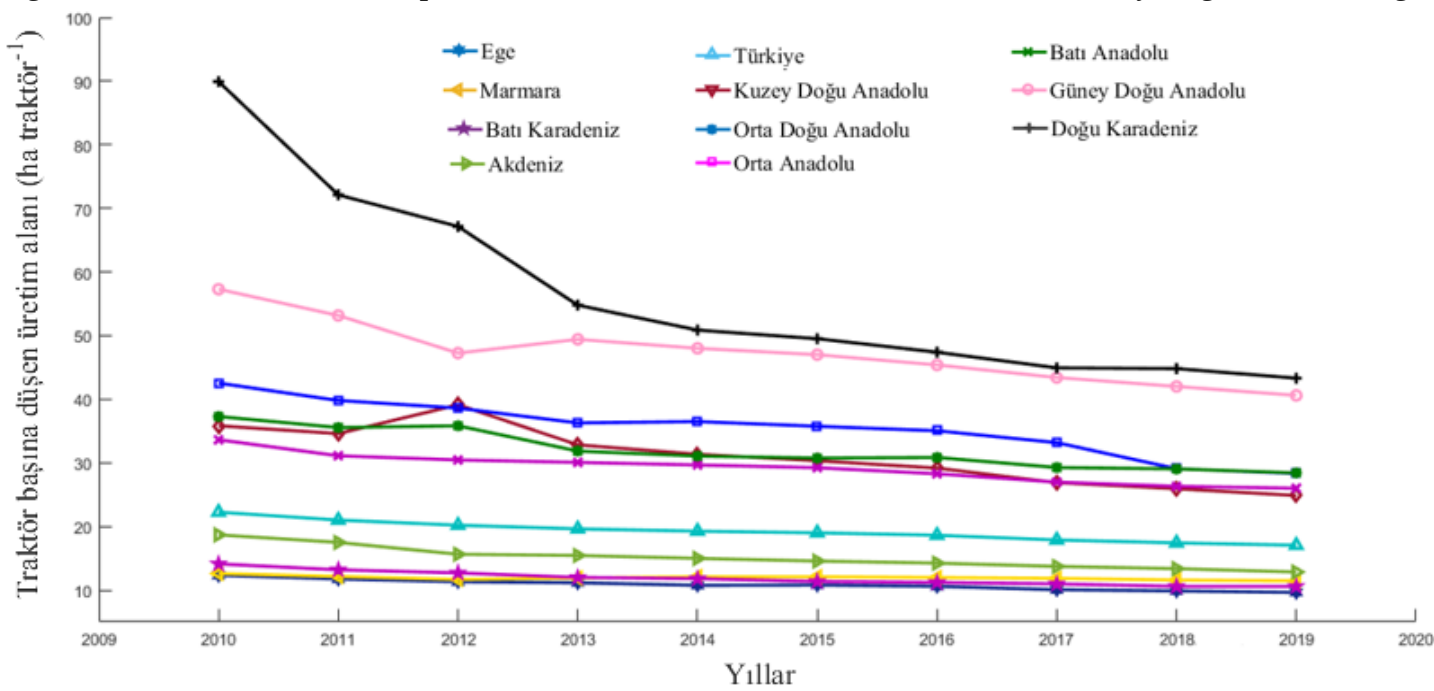

Şekil 3. Türkiye'nin tarım bölgelerinin 2010-2019 yıllarında traktör başına düşen üretim alanı (ha traktör $\left.{ }^{-1}\right)$ Figure 3. Production area per tractor (ha tractor ${ }^{-1}$ ) value of the Turkey's agricultural regions in 2010-2019 


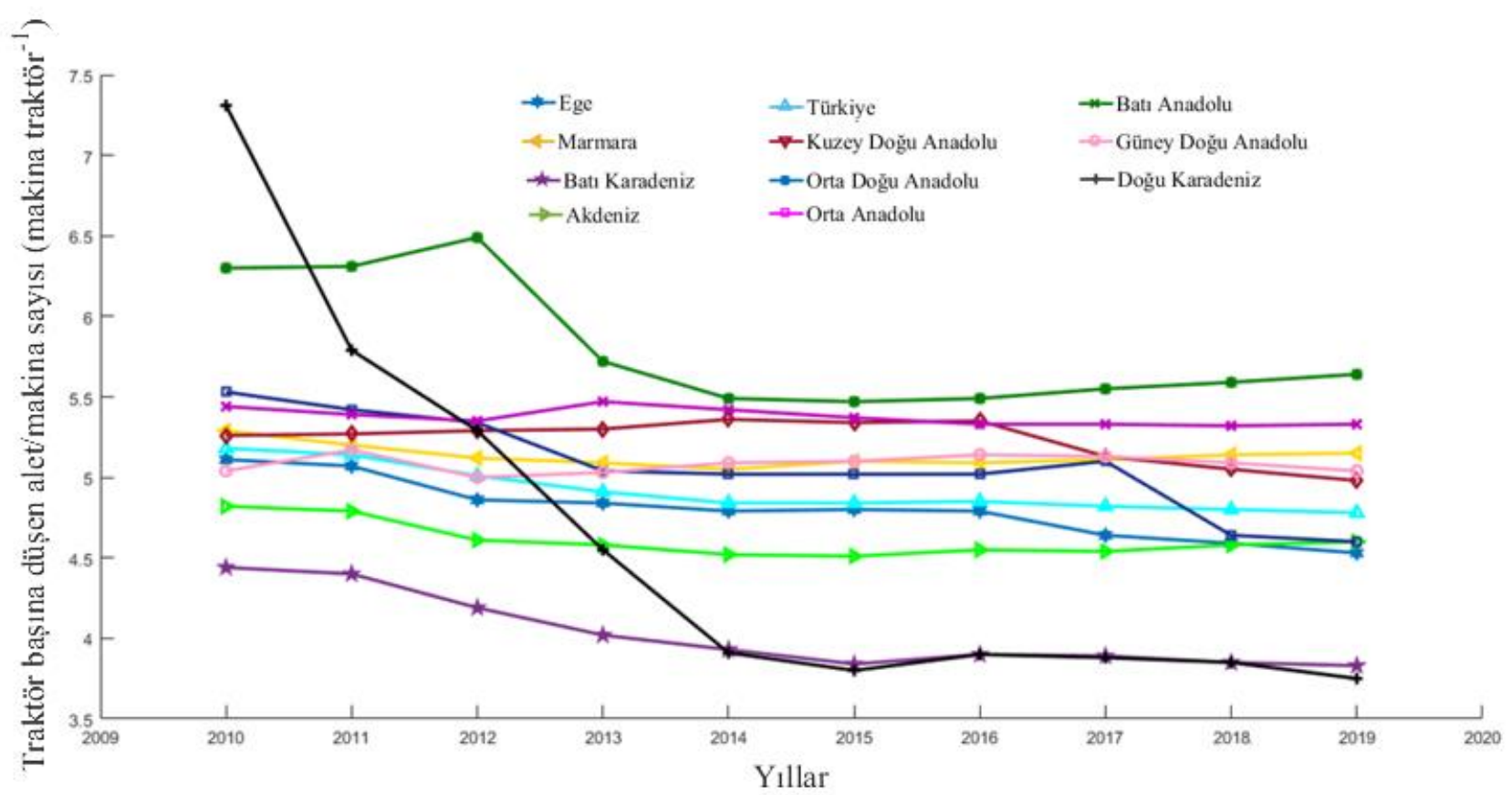

Şekil 4. Türkiye’nin tarım bölgelerinin 2010-2019 yıllarında traktör başına düşen alet/makina sayısı (makina traktör $\left.{ }^{-1}\right)$

Figure 4. Number of tools/machines per tractor (machine tractor ${ }^{-1}$ ) value of the Turkey's agricultural regions in 2010-2019

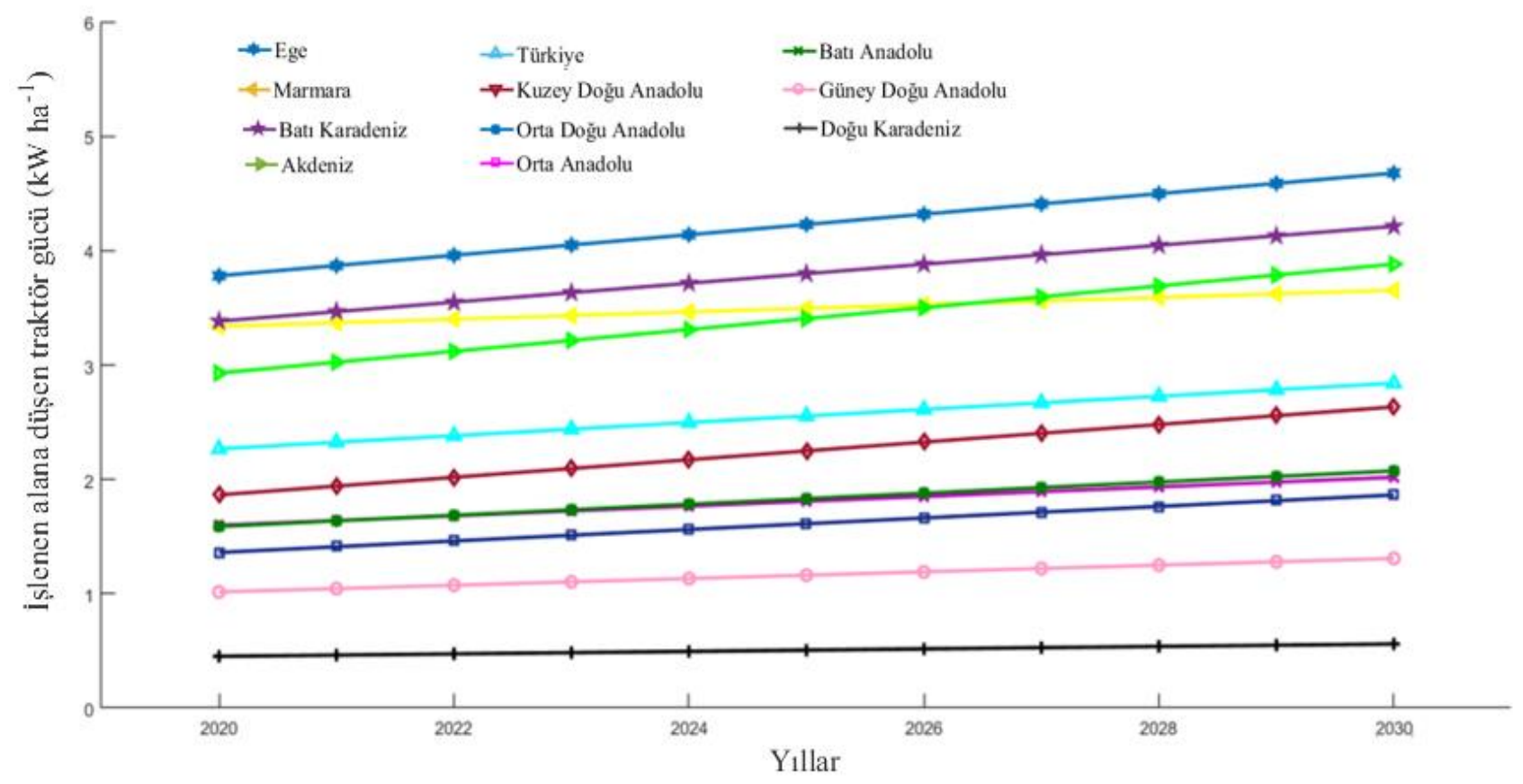

Şekil 5. Türkiye'nin tarım bölgelerinin 2020-2030 yıllarında trend analizi ile belirlenen işlenen alana düşen traktör gücü $(\mathrm{kW}$ ha-1) değerleri

Figure 5. Tractor power per unit cultivated area $\left(\mathrm{kW} \mathrm{ha}^{-1}\right)$ values of the Turkey's agricultural regions for the years 2020-2030 determined by trend analysis 
Çizelge 13. Türkiye'nin tarım bölgelerinin 2020-2030 yıllarında trend analizi ile belirlenen işlenen alana düşen traktör gücü $\left(\mathrm{kW} \mathrm{ha}^{-1}\right)$ değerleri

Table 13. Tractor power per unit cultivated area $\left(\mathrm{kW} \mathrm{ha}^{-1}\right)$ values of the Turkey's agricultural regions for the years $2020-2030$ determined by trend analysis

\begin{tabular}{|c|c|c|c|c|c|c|c|c|c|c|c|c|c|c|c|c|c|c|c|c|c|c|}
\hline & 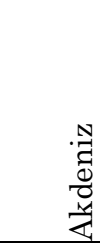 & & 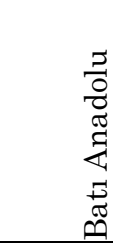 & & 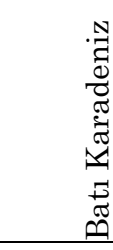 & & 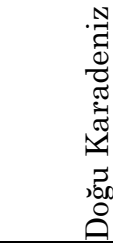 & & $\begin{array}{r}80 \\
80 \\
{[1}\end{array}$ & & 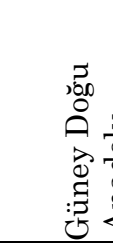 & & 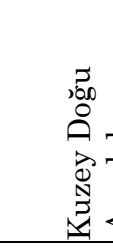 & & 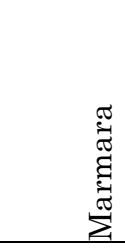 & & 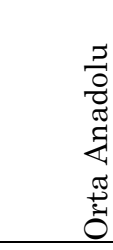 & & 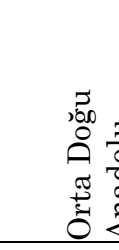 & & 胥 & \\
\hline$\underset{\nexists}{\nexists}$ & 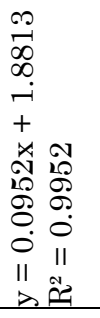 & 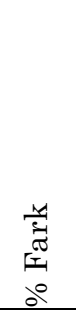 & 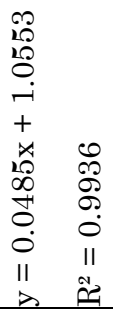 & 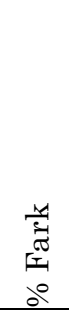 & 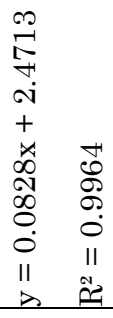 & 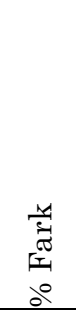 & 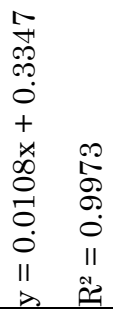 & 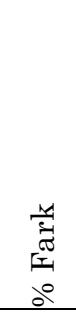 & 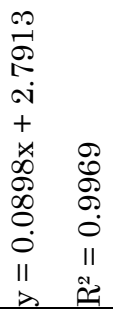 & 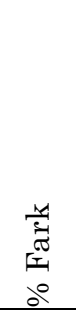 & 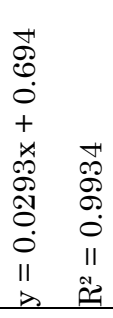 & 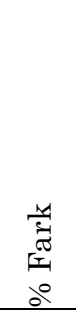 & 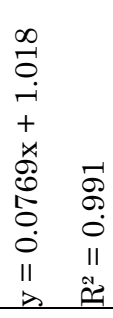 & 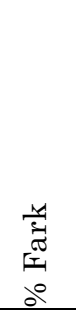 & 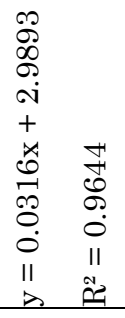 & 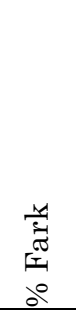 & 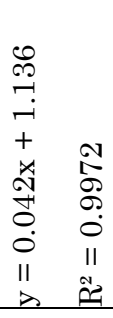 & 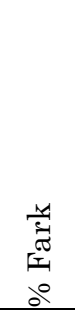 & 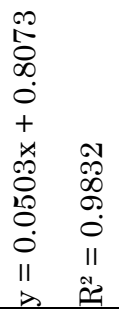 & 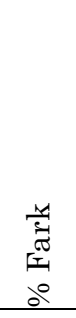 & 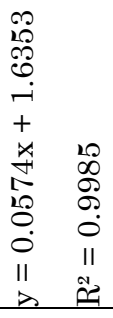 & 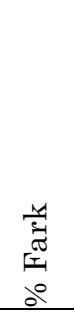 \\
\hline 2020 & 2.93 & & 1.59 & & 3.38 & & 0.45 & & 3.78 & & 1.02 & & 1.86 & & 3.34 & & 1.60 & & 1.36 & & 2.27 & \\
\hline 2021 & 3.02 & 3.07 & 1.64 & 3.14 & 3.47 & 2.66 & 0.46 & 2.22 & 3.87 & 2.38 & 1.05 & 2.94 & 1.94 & 4.30 & 3.37 & 0.90 & 1.64 & 2.50 & 1.41 & 3.68 & 2.32 & 2.20 \\
\hline 2022 & 3.12 & 3.31 & 1.69 & 3.05 & 3.55 & 2.31 & 0.47 & 2.17 & 3.96 & 2.33 & 1.07 & 1.90 & 2.02 & 4.12 & 3.40 & 0.89 & 1.68 & 2.44 & 1.46 & 3.55 & 2.38 & 2.59 \\
\hline 2023 & 3.21 & 2.88 & 1.73 & 2.37 & 3.63 & 2.25 & 0.49 & 4.26 & 4.05 & 2.27 & 1.10 & 2.80 & 2.09 & 3.47 & 3.43 & 0.88 & 1.72 & 2.38 & 1.51 & 3.42 & 2.44 & 2.52 \\
\hline 2024 & 3.31 & 3.12 & 1.78 & 2.89 & 3.71 & 2.20 & 0.50 & 2.04 & 4.14 & 2.22 & 1.13 & 2.73 & 2.17 & 3.83 & 3.46 & 0.87 & 1.77 & 2.91 & 1.56 & 3.31 & 2.50 & 2.46 \\
\hline 2025 & 3.40 & 2.72 & 1.83 & 2.81 & 3.80 & 2.43 & 0.51 & 2.00 & 4.23 & 2.17 & 1.16 & 2.65 & 2.25 & 3.69 & 3.49 & 0.87 & 1.81 & 2.26 & 1.61 & 3.21 & 2.55 & 2.00 \\
\hline 2026 & 3.50 & 2.94 & 1.88 & 2.73 & 3.88 & 2.11 & 0.52 & 1.96 & 4.32 & 2.13 & 1.19 & 2.59 & 2.33 & 3.56 & 3.53 & 1.15 & 1.85 & 2.21 & 1.66 & 3.11 & 2.61 & 2.35 \\
\hline 2027 & 3.60 & 2.86 & 1.93 & 2.66 & 3.96 & 2.06 & 0.53 & 1.92 & 4.41 & 2.08 & 1.22 & 2.52 & 2.40 & 3.00 & 3.56 & 0.85 & 1.89 & 2.16 & 1.71 & 3.01 & 2.67 & 2.30 \\
\hline 2028 & 3.69 & 2.50 & 1.98 & 2.59 & 4.05 & 2.27 & 0.54 & 1.89 & 4.50 & 2.04 & 1.25 & 2.46 & 2.48 & 3.33 & 3.59 & 0.84 & 1.93 & 2.12 & 1.76 & 2.92 & 2.73 & 2.25 \\
\hline 2029 & 3.79 & 2.71 & 2.03 & 2.53 & 4.13 & 1.98 & 0.55 & 1.85 & 4.59 & 2.00 & 1.28 & 2.40 & 2.56 & 3.23 & 3.62 & 0.84 & 1.98 & 2.59 & 1.81 & 2.84 & 2.78 & 1.83 \\
\hline 2030 & 3.88 & 2.37 & 2.07 & 1.97 & 4.21 & 1.94 & 0.56 & 1.82 & 4.68 & 1.96 & 1.31 & 2.34 & 2.63 & 2.73 & 3.65 & 0.83 & 2.02 & 2.02 & 1.86 & 2.76 & 2.84 & 2.16 \\
\hline Ort & & 2.85 & & 2.67 & & 2.22 & & 2.21 & & 2.16 & & 2.53 & & 3.53 & & 0.89 & & 2.36 & & 3.18 & & 2.27 \\
\hline
\end{tabular}


1000 ha $^{-1}$, ha traktör-1, $\mathrm{kW} \mathrm{ha}^{-1}$, makina sayısı traktör 1) belirlenmiş ve gelecek yullar (2020-2030) için mekanizasyon düzeyi $\left(\mathrm{kW} \mathrm{ha}^{-1}\right)$ gösterge değeri trend analizi yardımıyla tahmin edilmiş ve değerlendirilmiştir. Türkiye İstatistik Kurumundan alınan veriler (işlenen tarım alanları, traktör sayıları ve güç değerleri, tarım alet/makina sayıları) tarım bölgelerine göre işlenmiş ve mekanizasyon düzeyi gösterge değerleri hesaplanmıştır.

Çalışmada elde edilen sonuçlar şu şekilde özetlenebilir:

- Son on yılda, hem Türkiye genelinde hem de on tarım bölgesinde; işlenen tarım alanlarında bir azalma, traktör sayılarında artış, ortalama traktör güç değerlerinde Doğu ve Batı Karadeniz Bölgeleri hariç bir artış, toplam traktör güç değerlerinde bir artış, tarım alet/makina sayılarında bir artış olmuştur.

- Son on yılda, hem Türkiye genelinde hem de on tarım bölgesinde mekanizasyon düzeyi gösterge değerleri; $\mathrm{kW} \mathrm{ha-1}$ ve traktör $1000 \mathrm{ha}^{-1}$ 'da artış, ha traktör ${ }^{-1}$ ve makina traktör-1 ${ }^{-1}$ de azalma olmuştur.

- $\mathrm{kW} \mathrm{ha}^{-1}$ değeri; en yüksek Ege Bölgesinde (2.86$3.72 \mathrm{~kW} \mathrm{ha}^{-1}$ ), en düşük Doğu Karadeniz Bölgesinde (0.35-0.44 kW ha-1) oluşmuştur.

- Mekanizasyon düzeyinin artması/iyileşmesi traktör sayısı ve güç değerlerinin artması ve az da olsa işlenen tarım alanlarının azalmasından kaynaklanmaktadır. Ayrıca, ekonomik ömrünü dolduran traktörlerin yerine daha yüksek güce sahip traktörlerin satın alınması da işlenen alan başına traktör gücünü arttıran bir faktördür.

- Türkiye genelinde $\mathrm{kW} \mathrm{ha}^{-1}$ değeri son on yılda ortalama \%3.22 artış göstermiş ve $1.67-2.22 \mathrm{~kW}$ ha 1 olarak gerçekleşmiştir.

- ha traktör-1 değerindeki azalma, mekanizasyon düzeyinin arttığı veya iyileştiğinin bir ifadesidir.

- Makina traktör-1 oranındaki azalma; on yıllık süreçte makina sayılarındaki artış oranlarının traktör sayılarındaki artış oranlarından daha az olmasından kaynaklanmaktadır.

- $\mathrm{kW}$ ha-1 değeri; tüm tarım bölgelinde ve Türkiye genelinde gelecek yıllara göre artış olacağı beklenmektedir.

- $\mathrm{kW}$ ha-1 değeri; Türkiye geneli için 2020 yılında $2.27,2025$ yılında 2.55 ve 2030 yılında 2.84 olması tahmin edilmektedir.

Bu çalışmada elde edilen bulgular ve değerlendirmeler sonucunda konuya ilişkin aşağıdaki öneriler siralanabilir:

- Türkiye'de tarım arazilerinin parçalı ve dağınık olması traktör ve alet/makina kullanım etkinliğini sınırlamaktadır. Arazi toplulaştırma çalışmaları yaygınlaştırılarak hem yeni tarım alanlarının açılması sağlanabilecek hem de tarım makinalarının etkinliği arttırılabilinecektir.

- Çoğunlukla küçük ölçekli işletmelerin yer aldığı ülkemizde, daha ekonomik bir üretim için işletmelerin ihtiyaç duyduğu tarım alet/makinaları kullanabilmesini sağlayacak ortak makina kullanım sistemleri desteklemeler ile teşvik edilebilir.

- İşletmelerin, makina seçimi ve kullanımı konusunda eğitim almaları sağlanarak teknik bilgi ve becerileri arttırılmalıdır.

- Ekonomik ömrünü tamamlamış, iş sağlığı ve güvenliği yönünden de risk teşkil edebilecek traktör ve alet/makinaların yerine uygun teşvik ve hibelerle yeni teknolojilerin kullanılması sağlanarak işletmeler desteklenmelidir.

\section{Araştırmacıların Katkı Oranı Beyan Özeti}

Yazarlar makaleye eşit oranda katkı sağlamış olduklarını beyan eder.

\section{Çıkar Çatışması Beyanı}

Makale yazarları aralarında herhangi bir çıkar çatışması olmadığını beyan ederler.

\section{KAYNAKLAR}

Abdikoğlu Dİ 2019. Trakya Bölgesinde Tarımsal Mekanizasyon Düzeyinin İlere Göre Belirlenmesi. KSÜ Tarım ve Doğa Dergisi, 22(6):865-871.

Altuntaş E 2016. Türkiye'nin Tarımsal Mekanizasyon Düzeyinin Coğrafik Bölgeler Açısından Değerlendirilmesi. Türk Tarım - Gıda Bilim ve Teknoloji Dergisi, 4(12): 1157-1164.

Baran MF, Gökdoğan O, Durgut MR 2014. Batı Marmara Bölgesi'nin Tarımsal Mekanizasyon Özellikleri. Türk Tarım ve Doğa Bilimleri Dergisi 1(4): 561-567.

Bayram M, Altuntaş E 2016. Tokat İli’nin 2003 ve 2013 Yılları için Mekanizasyon Özelliklerindeki Değişiminin Incelenmesi, Tarım Makinaları Bilimi Dergisi, 12(3): 213-220.

Doğan Z, Arslan S, Berkman AN 2015. Türkiye'de Tarım Sektörünün İktisadi Gelişimi ve Sorunları: Tarihsel Bir Bakış. Niğde Üniversitesi, İktisadi ve İdari Bilimler Fakültesi Dergisi, 8(1): 29-41.

Ekinci K, Kulcu R, Kaya D, Yaldız O, Ertekin C 2010. The Prospective of Po-tential Biogas Plants That Can Utilize Animal Manure in Turkey. Energy Exploitation and Exploration, 28 (3): 187-206.

Evcim HÜ, Ulusoy E, Gülsoylu E, Tekin B 2010. Tarımsal mekanizasyon durumu sorunları ve çözüm önerileri. Türkiye Ziraat Mühendisleri VII. Teknik Kongresi Bildiriler Kitabı-2, Ankara s. 9891007.

Gökdoğan O 2012. Türkiye ve Avrupa Birliği’nin Tarımsal Mekanizasyon Düzeyi Göstergelerinin 
Karşılaştırılması. Adnan Menderes Üniversitesi Ziraat Fakültesi Dergisi 9(2): 1-4.

İleri MS 2010. Tarımsal Mekanizasyon Sektör Raporu, TARMAKBİR, Ankara.

Koçtürk D, Onurbaş Avcioğlu A 2007. Türkiye'de bölgelere ve illere göre tarımsal mekanizasyon düzeyinin belirlenmesi. Tarım Makinaları Bilimi Dergisi, 3(1): 17-24.

Korucu T, Aybek A, Sivrikaya F 2015. Türkiye'nin Tarım Bölgeleri Bazında Mekanizasyon Düzeyinin Yersel Değişim Haritalarının Oluşturulması ve Değerlendirilmesi. KSÜ Doğa Bilimleri Dergisi, 18(4): 77-90.

Landers A 2000. Resource management: farm machinery/selection, investment and management. Farming Press, United Kingdom, pp. 151.

Özgüven MM, Türker U, Beyaz A 2010. Türkiye'nin Tarımsal Yapısı ve Mekanizasyon Durumu. GOÜ, Ziraat Fakültesi Dergisi, 27(2): 89-100.

Ruiyin H, Wenqingv Y, Yadong Z, Van Sonsbeek G 1999. Improving management system of agricultural machinery in jiangsu. Proceedings of 99 International Conference on Agri. Engine, Beijing, China, pp. I-42-45

Sabanc1 A, Sümer SK, Say MS, Has M 2003. Türkiye'de Ekonomik Traktör Parkı ve Gelişimi.
Tarımsal Mekanizasyon 21. Ulusal Kongresi, 3-5 Eylül, Konya.

Sağlam C, Kuş ZA 2016. Orta Anadolu Bölgesi İllerinde Tarımsal Mekanizasyon Düzeyinin Yıllara Göre Değişimi. Nevşehir Bilim ve Teknoloji Dergisi TARGID Özel Sayı 364-371.

Say SM, Sabancı A, Başçetinçelik A, Özgüven F, Öztürk HH 2010. Tarım Makinaları1. Nobel Kitabevi Yayın Dağıtım ve Pazarlama Ltd. Şti. Adana.

TÜIK 2020. Türkiye İstatistik Kurumu. Tarımsal İstatistik Verileri. http://www.tuik.gov.tr (Erişim tarihi: Ocak-Mart 2020).

Ulusoy E, Türkay B, Has M, Dönder Ö, İleri S, Canoğlu S, Önal Ş, Bilgen H, Demir V, Yazgı A 2020. Tarım Makinaları Sanayinde Mevcut Durum ve Gelecek. Türkiye Ziraat Mühendisliği IX. Teknik Kongresi Bildiriler Kitabı-1, s 233-256, Ankara.

Witt SF, Witt CA 1992. Modeling and Forecasting Demand in Tourism. Academic Press, London, 208 s.

Yavuz H 2016. Hayvancillk Destekleme Politikalarının Tarımsal İşletmeler Açısından Değerlendirilmesi: Amasya İli Örneği. Gaziosmanpaşa Üniversitesi Fen Bil. Ens., Tarım Ekonomisi ABD, Yüksek Lisans Tezi, 110s. 